\title{
Preliminary Investigations of the Winter Ecology of Long-Billed Curlews in Coastal Texas
}

Open-File Report 2011-1312 



\section{Preliminary Investigations of the Winter Ecology of Long-Billed Curlews in Coastal Texas}

By Marc C. Woodin, Mary Kay Skoruppa, Jeremy W. Edwardson, and Jane E. Austin

Open-File Report 2011-1312 


\title{
U.S. Department of the Interior \\ KEN SALAZAR, Secretary \\ U.S. Geological Survey \\ Marcia K. McNutt, Director
}

\author{
U.S. Geological Survey, Reston, Virginia: 2012
}

For more information on the USGS - the Federal source for science about the Earth, its natural and living resources, natural hazards, and the environment, visit http://www.usgs.gov or call 1-888-ASK-USGS.

For an overview of USGS information products, including maps, imagery, and publications, visit http://www.usgs.gov/pubprod

To order this and other USGS information products, visit http://store.usgs.gov

Any use of trade, product, or firm names is for descriptive purposes only and does not imply endorsement by the U.S. Government.

Although this report is in the public domain, permission must be secured from the individual copyright owners to reproduce any copyrighted materials contained within this report.

Suggested citation:

Woodin, M.C., Skoruppa, M.K., Edwardson, J.W., and Austin, J.E., 2012, Preliminary investigations of the winter ecology of Long-billed Curlews in coastal Texas: U.S. Geological Survey Open-File Report 2011-1312, 17p. 


\section{Contents}

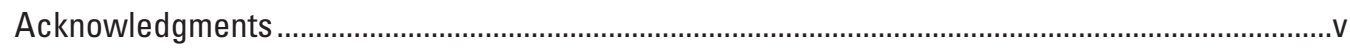

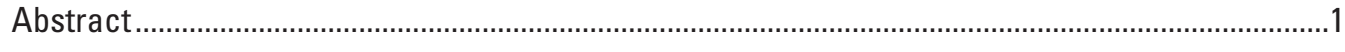

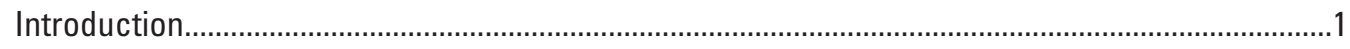

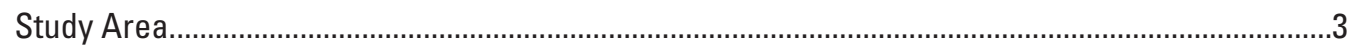

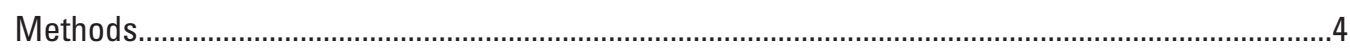

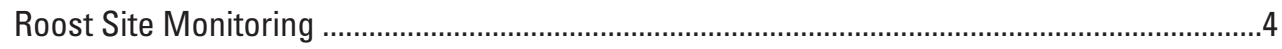

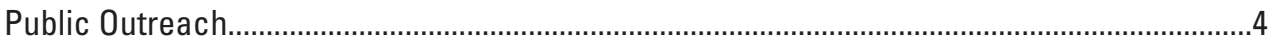

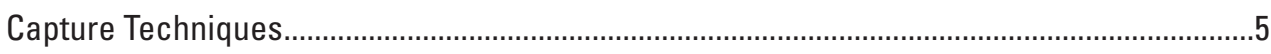

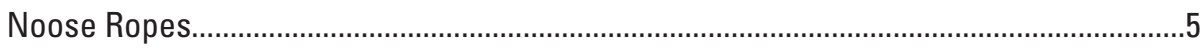

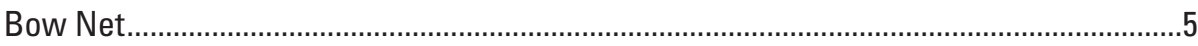

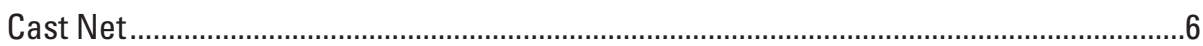

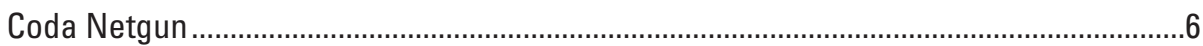

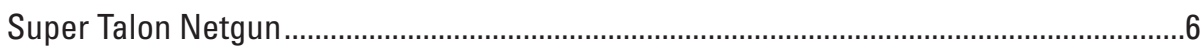

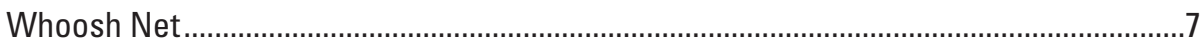

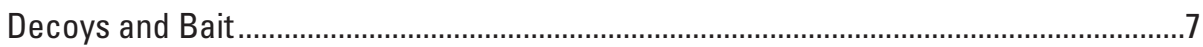

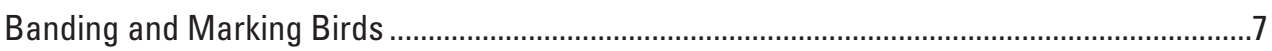

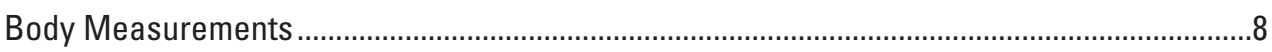

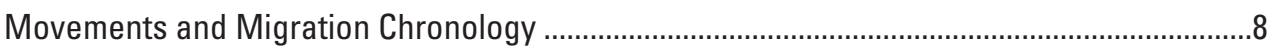

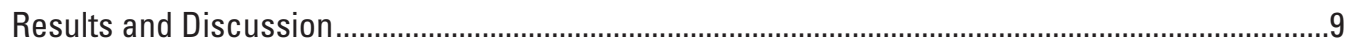

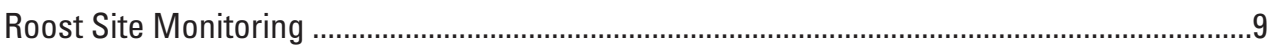

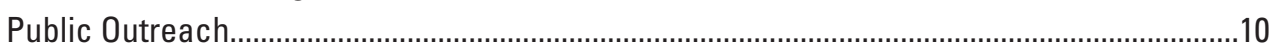

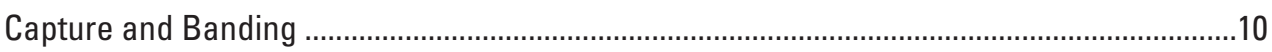

Capture Techniques........................................................................................................

Banding and Marking Birds ...............................................................................................13

Body Measurements ..........................................................................................................13

Movements and Migration Chronology .....................................................................................13

Conclusions and Recommendations for Future Studies .................................................................14

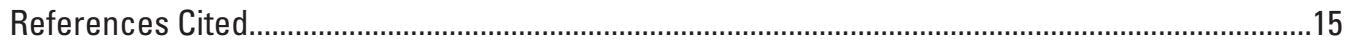

\section{Figures}

1. Map showing locations of Long-billed Curlew roost sites monitored in southern Texas during the winter of $2010-11$.................................................................................

2. Photograph showing Padre Island National Seashore beach.............................................

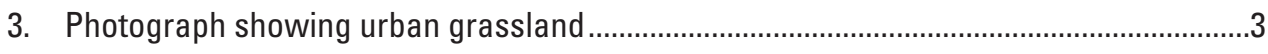

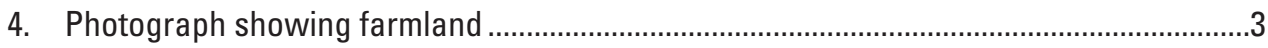

5. Photograph showing coastal salt marsh ............................................................................

6. Photograph showing East Lake, a naturally occurring saline lake, in Willacy

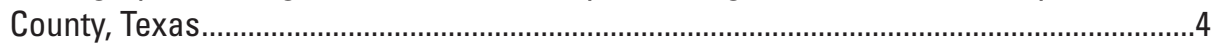

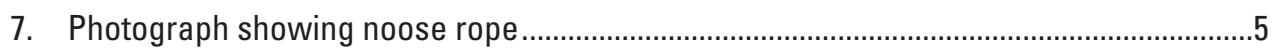

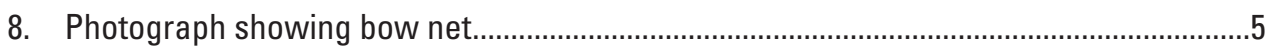

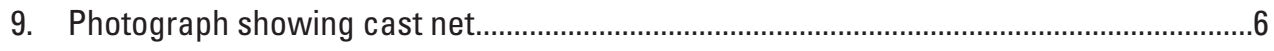

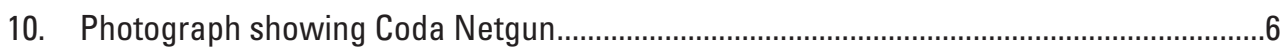

11. Photograph showing Super Talon Netgun .................................................................... 
12. Photograph showing whoosh net ..............................................................................

13. Photograph showing method for measuring the curvature of Long-billed Curlew

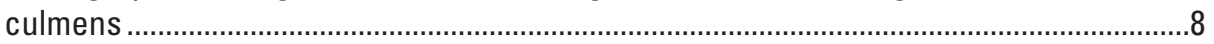

14. Photograph showing release of Long-billed Curlew from a holding box ..........................

15. Photograph showing band types and colors placed on Long-billed Curlews.................13

\section{Tables}

1. Locations, habitat types, and use by Long-billed Curlews of roost sites monitored in southern Texas during the winter of 2010-11

2. Numbers of locations and reports of Long-billed Curlew sightings by habitat type in response to public outreach methods.

3. Dates, locations, and techniques used in capture of Long-billed Curlews in southern Texas, 2010-11.

4. Measures of body mass and structural size of Long-billed Curlews captured and banded in southern Texas, 2010-11

\section{Conversion Factors and Abbreviations}

\begin{tabular}{|c|c|c|}
\hline \multicolumn{3}{|l|}{ SI to Inch/Pound } \\
\hline Multiply & By & To obtain \\
\hline \multicolumn{3}{|c|}{ Length } \\
\hline centimeter $(\mathrm{cm})$ & 0.3937 & inch (in.) \\
\hline meter (m) & 3.281 & foot (ft) \\
\hline kilometer $(\mathrm{km})$ & 0.6214 & mile (mi) \\
\hline meter $(\mathrm{m})$ & 1.094 & yard (yd) \\
\hline \multicolumn{3}{|c|}{ Area } \\
\hline square meter $\left(\mathrm{m}^{2}\right)$ & 0.0002471 & acre \\
\hline hectare (ha) & 2.471 & acre \\
\hline square centimeter $\left(\mathrm{cm}^{2}\right)$ & 0.001076 & square foot $\left(\mathrm{ft}^{2}\right)$ \\
\hline square meter $\left(\mathrm{m}^{2}\right)$ & 10.76 & square foot $\left(\mathrm{ft}^{2}\right)$ \\
\hline square centimeter $\left(\mathrm{cm}^{2}\right)$ & 0.1550 & square inch $\left(\mathrm{ft}^{2}\right)$ \\
\hline hectare (ha) & 0.003861 & square mile $\left(\mathrm{mi}^{2}\right)$ \\
\hline \multicolumn{3}{|c|}{ Volume } \\
\hline milliliter (ml) & 0.33814 & fluid ounce (fl oz) \\
\hline cubic meter $\left(\mathrm{m}^{3}\right)$ & 264.2 & gallon (gal) \\
\hline cubic meter $\left(\mathrm{m}^{3}\right)$ & 35.31 & cubic foot $\left(\mathrm{ft}^{3}\right)$ \\
\hline \multicolumn{3}{|c|}{ Mass and Density } \\
\hline $\operatorname{gram}(\mathrm{g})$ & 0.03527 & ounce, avoirdupois (oz) \\
\hline $\mathrm{g} / \mathrm{m}^{2}$ (gram per square meter) & 0.0002 & pound per square foot $\left(\mathrm{lb} / \mathrm{ft}^{2}\right)$ \\
\hline
\end{tabular}

Temperature in degrees Celsius $\left({ }^{\circ} \mathrm{C}\right)$ may be converted to degrees Fahrenheit $\left({ }^{\circ} \mathrm{F}\right)$ as follows: ${ }^{\circ} \mathrm{F}=\left(1.8 \mathrm{x}^{\circ} \mathrm{C}\right)+32$

Temperature in degrees Fahrenheit $\left({ }^{\circ} \mathrm{F}\right)$ may be converted to degrees Celsius $\left({ }^{\circ} \mathrm{C}\right)$ as follows: ${ }^{\circ} \mathrm{C}=\left({ }^{\circ} \mathrm{F}-32\right) / 1.8$ 


\section{Acknowledgments}

This project was funded by the Science Support Program of the U.S. Geological Survey. The authors are grateful to Bill Howe (U.S. Fish and Wildlife Service, Region 2) and Stephanie Jones and Suzanne Fellows (U.S. Fish and Wildlife Service, Region 6), who were instrumental in the planning and development of the study. The authors also are thankful to the staff at the Lower Rio Grande Valley National Wildlife Refuge, Padre Island National Seashore, Naval Air StationCorpus Christi of the U.S. Department of Defense, and the Coastal Bend Bays \& Estuaries Program, Inc., for access to properties and logistical support for this project.

The authors are indebted to Dr. Roger Pigott (DVM), who graciously gave his time to consult with us on care and handling of large-bodied birds and advised us on remedial measures in case we encountered muscle myopathy in captured curlews. This research benefitted from many volunteers who helped in the field. They include Clint Jeske, Chad Stinson, Beau Hardegree, Clare Lee, Nancy Mitton, Wade Stablein, Chris Perez, Shaunette Gillespie, Cody Lynch, Loren Gallo, Tommy Skoruppa, Joni Edwardson, Jon Thomas Skoruppa, and Roy Wessels.

We thank the many private landowners who graciously allowed us access to their properties, and are especially grateful to the residents of Rancho Allegre in Bluntzer, Texas, and the Southside Community Church in Corpus Christi, Texas.

Assistance with field equipment and techniques was provided by Caesar Kleberg Wildlife Research Institute. Additional scientific expertise and technical advice were provided by David Blankinship, Tom Langschied, Brent Ortego, David Haley, David Newstead, Gene Blacklock, Sonia Najera, Martin Hagne, Brad Strobel, and Jonathan Moczygemba. The authors are indebted to Suzanne Fellows and Marsha Sovada for reviewing earlier versions of this report. 



\title{
Preliminary Investigations of the Winter Ecology of Long- billed Curlews in Coastal Texas
}

\author{
By Marc C. Woodin, Mary Kay Skoruppa, Jeremy W. Edwardson, and Jane E. Austin
}

\section{Abstract}

Since the early 1900s, the distribution of the Long-billed Curlew (Numenius americanus) has contracted dramatically in the eastern one-half of its historic range. The species has been designated as a "Bird of Conservation Concern" and focal species by the U.S. Fish and Wildlife Service, a species of concern by several states, and a "Highly Imperiled" species in the U.S. Shorebird Conservation Plan. The uncertain outlook for this species has contributed to a plethora of research on Long-billed Curlews, most of which have focused on breeding and nesting ecology of the species. Gaps remain in information about factors affecting population dynamics on the winter grounds and the linkages between Long-billed Curlew populations on the breeding range, migration routes, and winter range. To begin filling those gaps, a pilot study was done to evaluate (1) curlew use of nocturnal roost sites, (2) use of public outreach to locate curlews and contribute to preliminary assessment of foraging habitat use, (3) six different methods to capture curlews, and (4) movements by curlews on wintering areas. The study area includes the lower Texas coast, which harbors the eastern-most dense populations of Long-billed Curlews in North America.

Use of historical winter roost sites was not observed; however, there was documented limited use (up to 150 curlews) of several new roost sites, some of which were used on an intermittent or erratic basis. Reports elicited from the public indicated Long-billed Curlews wintering in coastal Texas often forage in open, grass-covered lots of partially developed residential areas, golf courses, and public parks within urban and suburban zones. Curlews were reported to use these sites in developed areas as far as 100 kilometers inland. Other reports indicated Long-billed Curlews foraging in farm fields, shallow coastal marsh, and on the beaches of Gulf of Mexico barrier islands.

The effectiveness of six techniques for capture of Longbilled Curlews was evaluated in the study. Seven curlews were captured and banded with four of six methods attempted. At least one curlew each was captured with (1) noose ropes, (2) baited bow net, (3) Coda Netgun, and (4) whoosh net; no curlews were caught with a cast net or Super Talon netgun. The Coda Netgun proved to be the most effective methodology examined. Captured birds (7) were weighed, measured, and banded. Body masses (mean $=518$ grams) were low compared to data previously published on body mass of Long-billed Curlews. There were 22 observations recorded of banded curlews. Resightings confirmed that birds were not harmed during capture. All of the 22 resightings occurred within two kilometers of the banding locations, suggesting that birds remained near their chosen foraging areas.

Results from this 1-year pilot study yielded an intriguing combination of findings that warrant further investigation. Observations include reduced numbers of roosting birds along the Texas coast during dry conditions, highly dynamic use of nocturnal roost sites, use of widely divergent habitat types for foraging, low body mass of most captured birds, and apparent fidelity to general feeding areas. Future investigations of this eastern winter population of curlews would benefit from larger sample sizes and monitoring of individual birds.

\section{Introduction}

The breeding distribution of Long-billed Curlew (Numenius americanus), the largest shorebird species in North America, once extended across the grasslands of the United States, but its distribution has contracted dramatically in the eastern one-half of its historic range. The change is attributed primarily to excessive harvest in the late 1800 s and early 1900 s by market hunters and loss of grasslands in their breeding range (Dugger and Dugger, 2002). The wetlands and grasslands of the Texas coastal plain now harbor the largest, eastern-most populations of wintering Long-billed Curlews in North America (Dugger and Dugger, 2002). The species has been identified as a "Bird of Conservation Concern" and focal species by the U.S. Fish and Wildlife Service (USFWS; U.S. Fish and Wildlife Service, 2008), a species of concern by several states, and a "Highly Imperiled" species in the U.S. Shorebird Conservation Plan. Canada has a variety of designations as well, including "Species of Special Concern" and "Blue Listed." Uncertainties abound about curlew population affiliations among winter, migration and breeding areas, and factors limiting curlew populations (Dugger and Dugger, 2002). Studies of reproductive ecology, nest success, courtship and breeding 


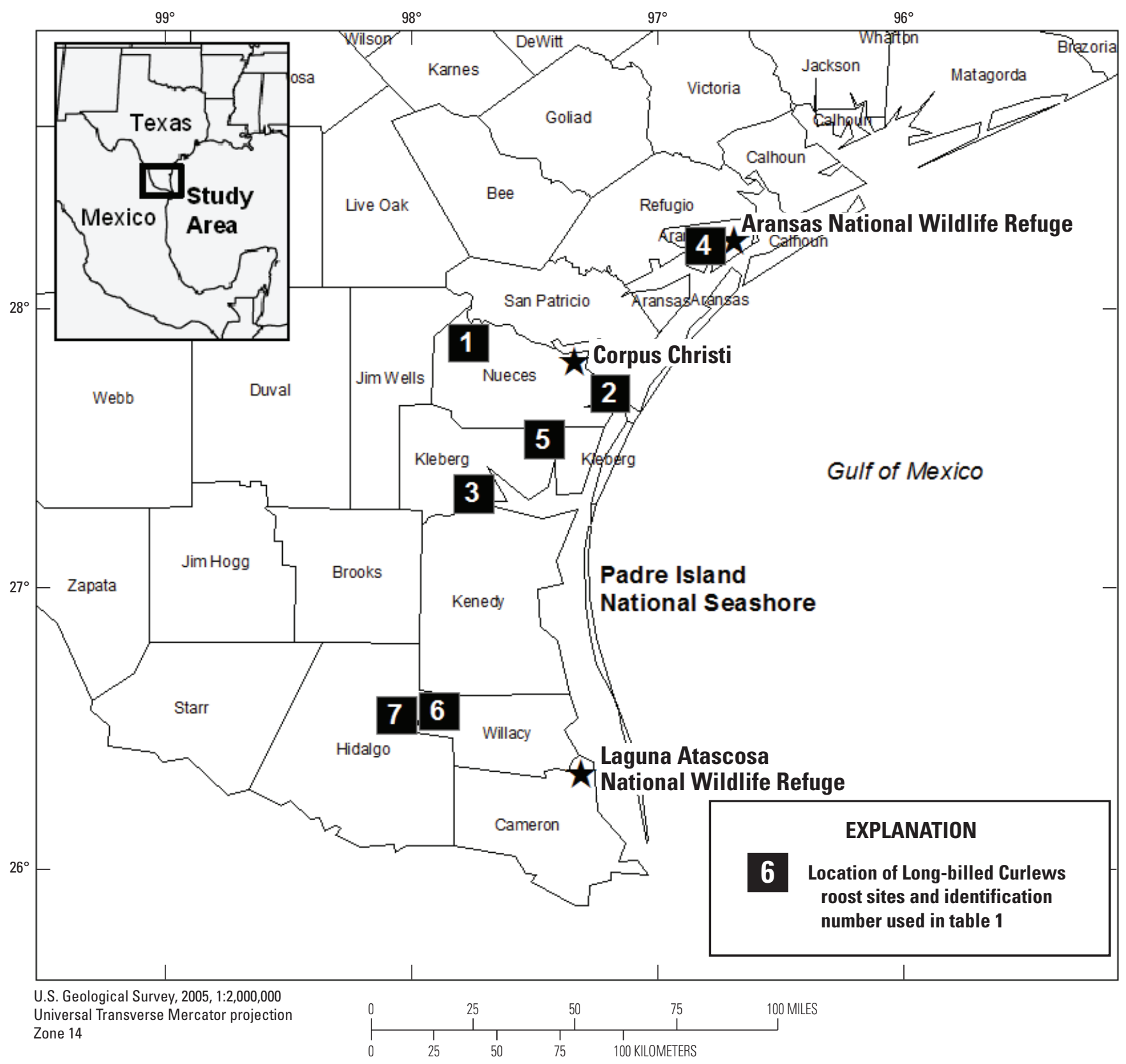

Figure 1. Locations of Long-billed Curlew roost sites monitored in southern Texas during the winter of 2010-11.

behavior, and foraging ecology of Long-billed Curlews have been completed in various locations in the western United States (for example, Redmond and Jenni, 1986; Pampush and Anthony 1993; Clarke, 2006). Additionally, a range-wide estimate of the continental breeding population was made in 2008 (Jones and others, 2008). For curlews breeding in the Great Basin and wintering in California (not shown), their migratory pathways, foraging ecology, social organization, and winter habitats also have been studied (Leeman and others, 2001; Danufsky and Colwell, 2003; Patton and Dalton, 2004).

In contrast, the winter and migration ecology of Longbilled Curlews in the central portion of the United States is almost unknown, aside from a study of birds wintering in arid, inland grasslands of Nuevo León, México (not shown;
Olalla-Kerstupp, 2010). There is little information about the winter ecology, migration pathways, and breeding ground affiliations of curlews wintering in coastal Texas, which is considered one of the main wintering areas for Long-billed Curlews in North America (Dugger and Dugger, 2002). Even basic information is lacking, such as numbers, locations of and numbers of roost sites, local movements, habitat use, migration routes, staging areas, and location of the birds' breeding grounds. Such data are needed by migratory bird biologists and land managers to make informed management decisions and for targeting conservation areas critical to the winter and migration needs of Long-billed Curlews.

Objectives for this 1-year pilot study of wintering Long-billed Curlews were to (1) describe locations and 
characteristics of roost sites and their use by Long-billed Curlews on the lower Texas coast, concentrating on the area between Aransas National Wildlife Refuge and Laguna Atascosa National Wildlife Refuge; (2) use public outreach to locate curlews and contribute to preliminary assessment of foraging habitat use; (3) evaluate techniques to capture Longbilled Curlews on the wintering grounds, and (4) begin to describe local movement patterns and migration chronology.

\section{Study Area}

The study area was located in two Texas ecoregions. Study sites in Refugio, Nueces, and Kleberg counties were in the Gulf Coast Prairies and Marshes ecoregion (not shown), which extends from Orange County to the Mexico border. Inland study sites in Willacy and Hidalgo counties were in the South Texas Plains ecoregion (not shown; Texas Parks and Wildlife Department, 2005; modified from Gould and others, 1960) (fig. 1). These semiarid study site supports subtropical representatives of native grasses such as Schizachyrium, Chloris, Eragrostis, and Paspalum spp.; however, many grasslands are now dominated by exotic grasses such as buffelgrass (Cenchrus ciliaris), Johnsongrass (Sorghum halepense), Kleberg bluestem (Dichanthium annulatum), and kleingrass (Panicum coloratum). Typical woody vegetation of the region includes honey mesquite (Prosopis glandulosa), live oak (Quercus virginiana), and Texas prickly pear (Opuntia engelmannii).

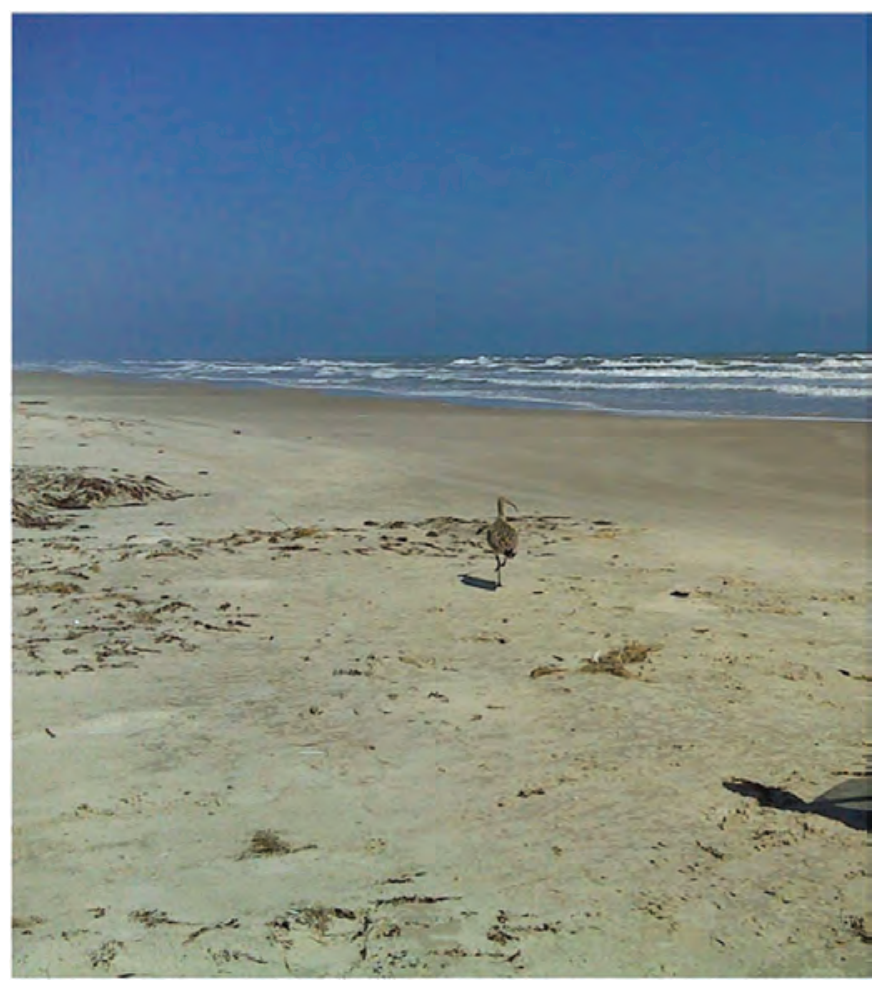

Figure 2. Padre Island National Seashore beach.

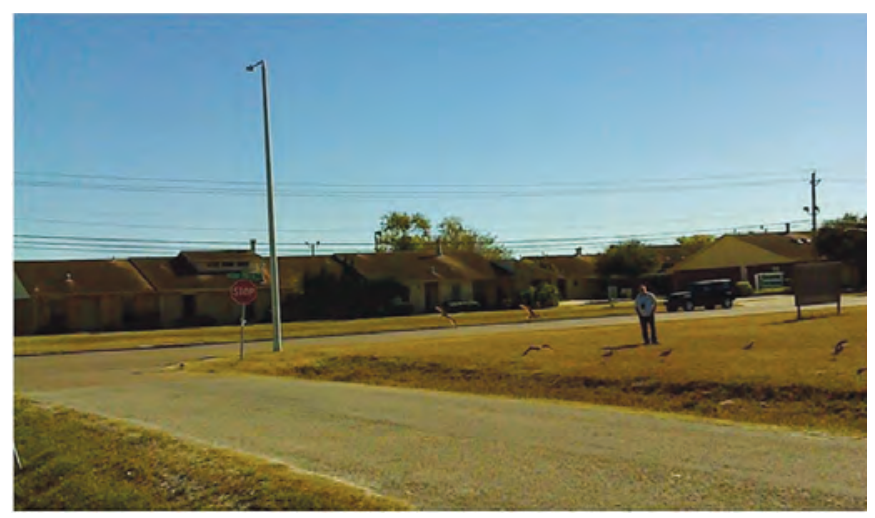

Figure 3. Urban grassland.

Long-billed Curlew research was conducted in a variety of habitats in southern Texas, including barrier island beach, urban and suburban mowed grassland, farmland, salt marsh, and inland saline lakes (figs. 2-6). Beach habitat (fore beach/ surf and back beach with associated coppice dunes) on Padre Island was characterized by washed up mats of brown algae (Sargassum), beach debris, and sparse vegetation, including morning glory (Ipomoea pes-caprae and Ipomoea imperati)

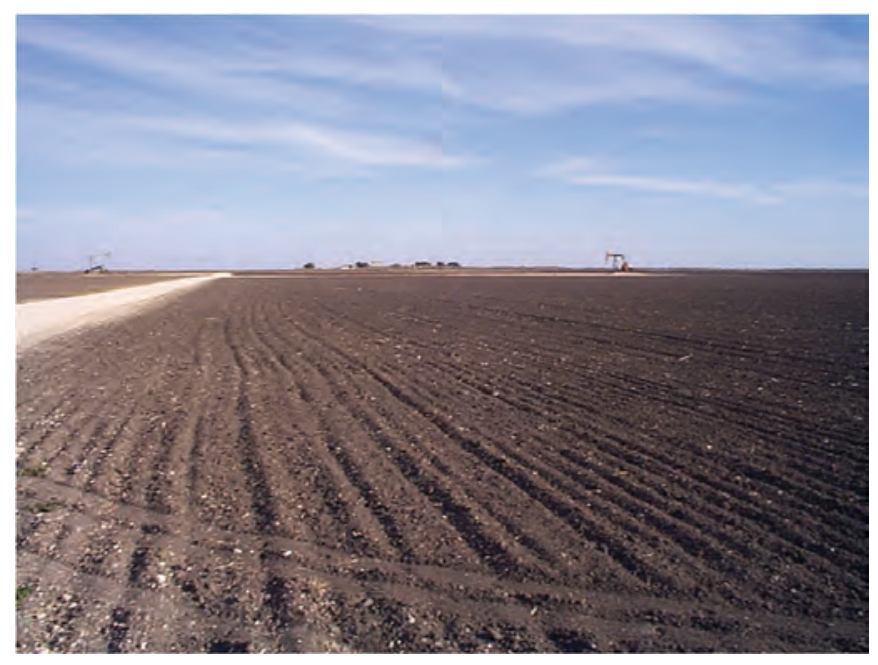

Figure 4. Farmland.

and coastal panicgrass (Panicum amarulum). Coastal marshes affected by tides were characterized by plants such as saltwort (Batis maritima), glasswort (Salicornia bigelovii), bushy seaoxeye (Borrichia frutescens), and black mangrove (Avicennia germinans), a recent invader. Long-billed Curlews also occurred in open residential neighborhoods, undeveloped commercial property lots, city parks, golf courses, and other mowed areas, many of which received regular human use. These urban and suburban areas were often small (less than 1 hectare, ha) areas with few or no trees, and ranged from sparsely vegetated mixes of forbs and grasses to monotypic stands of exotic grasses. Grass height rarely exceeded 15 centimeters $(\mathrm{cm})$. Farmland consisted of 


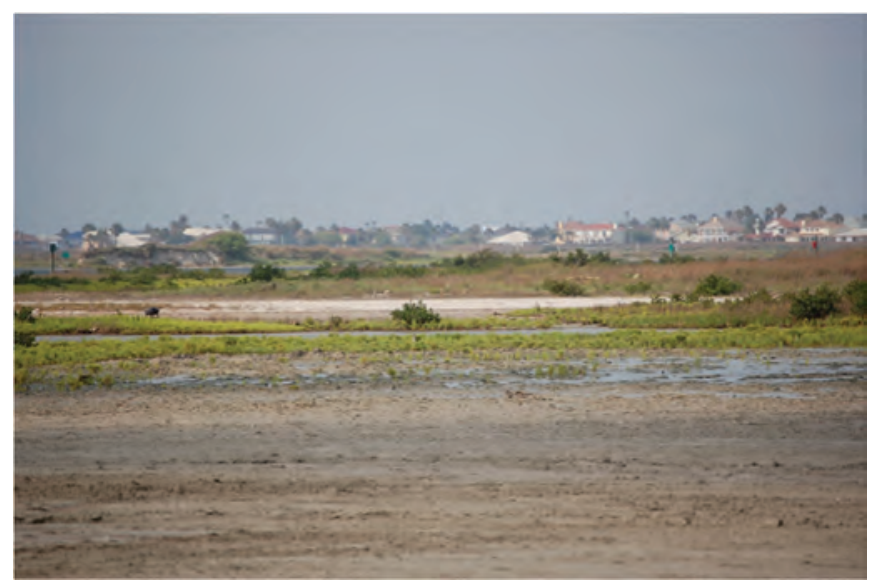

Figure 5. Coastal salt marsh.

idle, plowed fields (some containing stubble, but most were unvegetated), and narrow strips of mowed grass. Inland salt lakes were large (200-300 ha), naturally occurring, shallow, hypersaline lakes surrounded by grassland and Tamaulipan thornscrub vegetation, a subtropical, semiarid vegetation type (Crosswhite, 1980). These saline lakes are free of any aquatic vegetation and at times host large numbers of Brine Shrimp (Artemia spp.), attractive to many waterbirds.

Grantham (2011) reported that the cool season (November-February) for Corpus Christi, Texas in 2010-11 was colder and drier than average. These conditions may have altered foraging and roosting habitats for Long-billed Curlews in southern Texas. Southern Texas had $2.24 \mathrm{~cm}$ less rainfall during the cool season compared to historical averages (1950-2011). Rainfall in November and December 2010 was $1.85 \mathrm{~cm}$ and $2.46 \mathrm{~cm}$ below average, respectively, and average

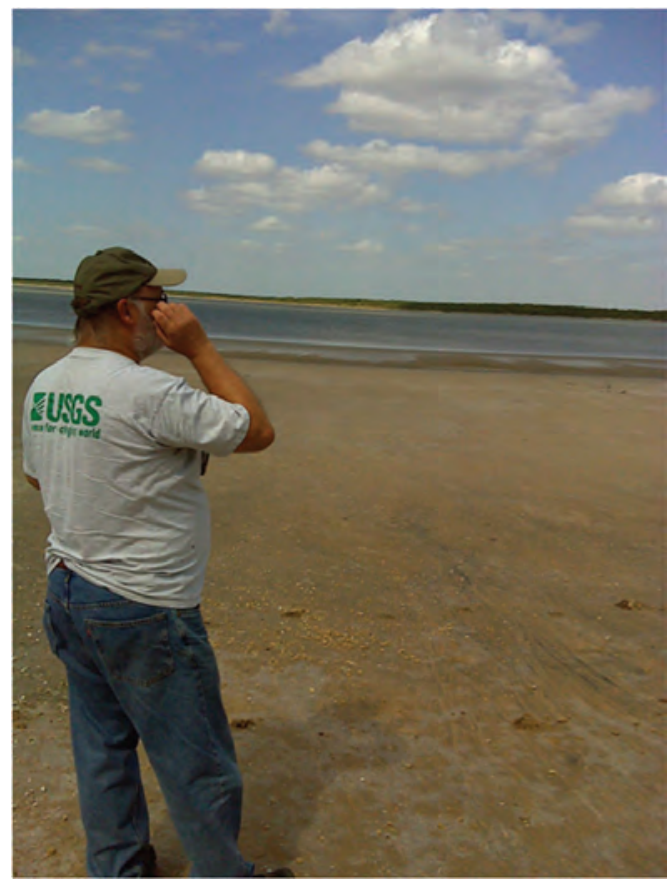

Figure 6. East Lake, a naturally occurring saline lake, in Willacy County, Texas. rainfall in February 2011 was $4.04 \mathrm{~cm}$ below historical rainfall measurements. January 2011, however, was an exceptionally wet month with $10.19 \mathrm{~cm}$ of rainfall, $6.12 \mathrm{~cm}$ more than the historical average (Grantham, 2011). In addition to the high rainfall, January 2011 experienced strong storms, including the first tornado recorded in Nueces County for the month of January (Buchanan, 2011).

Corpus Christi also experienced a colder cool season than historical averages. Twelve freezes occurred during the 2010$11 \mathrm{cool}$ season in Corpus Christi, compared to the historical average of 5.4 freezes. In addition, temperatures less than or equal to $4^{\circ} \mathrm{C}$ were recorded 35 times throughout the season, compared to the historical average of 23.5 times throughout the season. One cold stretch occurred February 3-5, 2011, yielding record lows, with the coldest 3-day period since 1989 (Gittinger and Buchanan, 2011).

\section{Methods}

\section{Roost Site Monitoring}

Traditional winter roost sites were located by soliciting information from biologists and ornithologists in the region who have knowledge of national wildlife refuges, private ranches, and conservation preserves within the study area. Traditional roost sites were visited periodically (approximately once/month) at dusk to verify use and assess abundance of curlews at each site. Volunteers visited smaller historical roost sites and provided information on numbers of curlews roosting there. New roost sites were sought by following flight lines of curlew flocks as they flew toward nocturnal roosts in the early evening.

\section{Public Outreach}

More than 91percent of Texas is in private ownership (U.S. Department of Agriculture, 2000) and not readily accessible for scientific studies. Because of this, an outreach program enlisted help from the public to locate Long-billed Curlews and their roost sites. The outreach program provided information to the public through newspaper articles in the Corpus Christi Caller-Times (Sikes, 2011), a flier, postings on TexBirds [a listserve dedicated to bird reports in Texas (http:// moonmountaingroup.com/texbirds/)], and a local birding club newsletter (Coastal Bend Audubon Society, 2010). An email account for citizens to communicate with the U.S. Geological Survey (USGS) project personnel was provided through the outreach outlets. An interview with a Corpus Christi television station (KIII-TV, an ABC affiliate) for a Saturday morning birding show also was used to request assistance from the community and to provide information about Long-billed Curlew conservation.

Information provided on Long-billed Curlew sightings was recorded and kept in a reference file. When possible, the 
following information was collected from the person reporting a sighting: (1) approximate number of Long-billed Curlews;

(2) exact location; (3) date and time of day; (4) habitat type;

(5) general behavior of birds; and (6) name and phone number of person making the report (optional). Most new locations were visited to confirm curlew sightings, record habitat information, and to evaluate the locations as potential trapping sites.

\section{Capture Techniques}

The objective of this research component was to evaluate effectiveness of different techniques for capturing Long-billed Curlews on their winter grounds with minimal likelihood of injury. Multiple capture techniques were used to determine their effectiveness, including (1) modified noose carpets, (2) remote-controlled bow nets, (3) hand-thrown cast net, (4) Coda Netgun, (5) Super Talon netgun, and (6) Hawkseye whoosh net. Use of curlew decoys and bait (earthworms and giant mealworms) also were evaluated for their ability to increase capture efficiency. Trapping was not attempted at nocturnal roost sites to avoid disturbance to large numbers of communally roosting curlews, and to minimize risk of injury to densely clustered birds.

\section{Noose Ropes}

Mehl and others (2003) successfully used leg-hold noosemats to capture wintering shorebirds, and Olalla-Kerstupp (2010) captured wintering Long-billed Curlews in Mexico with similar noose carpets. In this study, "noose ropes" were modified noose carpets constructed by attaching monofilament [5.4-kilogram (kg) test, low visibility green] nooses with a

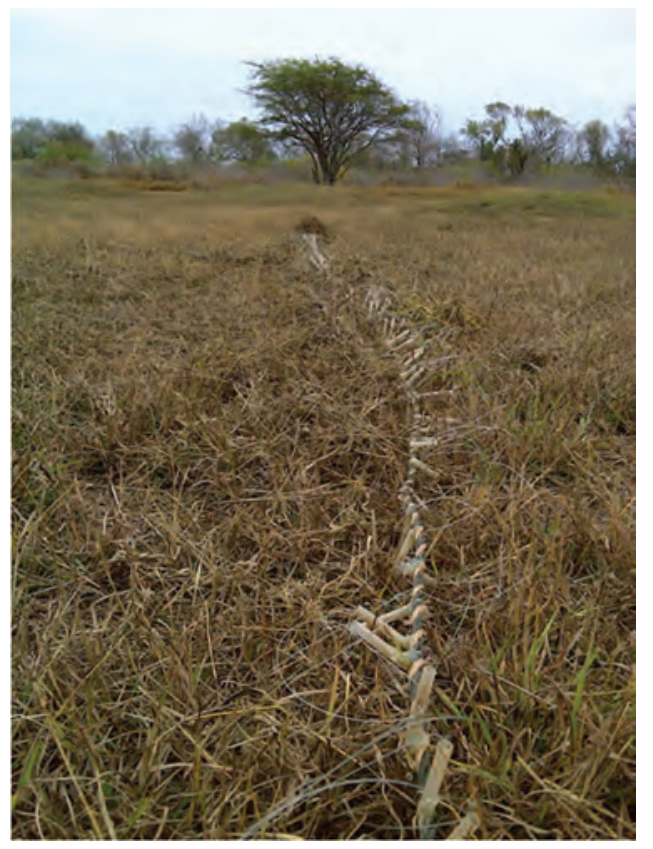

Figure 7. Noose rope. circumference of 8-18 cm along camouflage-colored nylon ropes 2-3.5 meter (m) long (fig. 7). The nooses were spaced about $4 \mathrm{~cm}$ apart along the ropes. Lead fishing weights [454 grams (g)] were attached at each end of the rope. Noose ropes were placed in fields on the projected path of foraging curlews and birds were then herded (Hicklin and others, 1989) toward the location of the noose ropes to increase the chance of a bird walking over the nooses. A successful capture required that a bird's toe or foot catch a noose and then close tightly around the bird's toe or foot as the bird moved forward. The weights at the end of the rope prevented the bird from flying away until the bird could be secured safely in hand.

Early in the field season, the noose rope design was improved by gluing $5-\mathrm{cm}$ sections of clear plastic drinking straws at the base stem of the nooses to keep the nooses standing erect, thereby increasing the likelihood of a curlew becoming ensnared in the noose. The straws were painted a sandy color to camouflage their appearance. To decrease the visibility of the noose ropes, grass clippings or sand were scattered over and alongside the rope. Also, with experience gained with time, noose ropes were used only on cloudy or overcast days to reduce the sun's reflection from the monofilament.

\section{Bow Net}

The bow net (Northwoods Limited, Rainier, Washington) is a $152-\mathrm{cm}$ diameter nylon net mounted on a circular, folding aluminum frame. The bow net was staked to the ground in an open position (forming a half circle) and sprung closed by a battery-operated remote trigger (fig. 8). In order to capture a bird with the bow net, the bird must walk into the target area of the opened bow net. A dummy bow net (permanently secured in the open position) was placed for 2 days at each

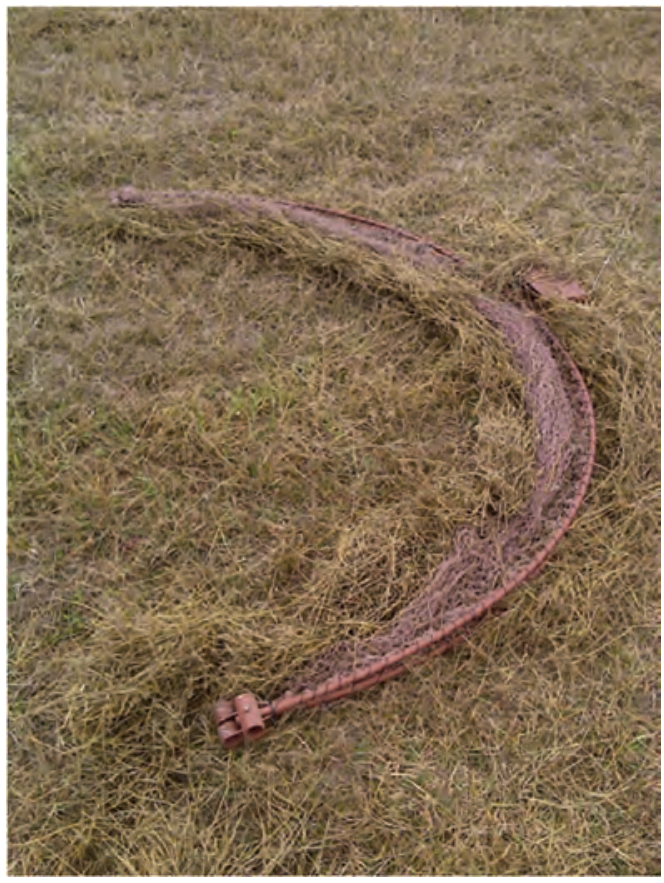

Figure 8. Bow net. 
foraging site for the curlews to become habituated to its presence. Earthworms or giant mealworms were placed in the target area of the dummy bow net when Long-billed Curlews were foraging nearby, to lure the birds into to the bow net. When curlews began to associate the bow net with plentiful prey, the dummy bow net was replaced with a baited, remotecontrolled bow net for capture.

\section{Cast Net}

The cast net was a hand-held circular net (2.4-m diameter) with numerous small weights attached to the perimeter (fig. 9). Cast nets are used by fishermen to catch small baitfish and are available commercially at most sporting goods stores. The net is flung over the bait, and a long cord attached to the wrist allows the fisherman to close and retrieve the net along with its contents. Cast nets were evaluated because of the ability to get close (within $3 \mathrm{~m}$ ) to foraging curlews in urban environments. Long-billed Curlews were approached by a single person carrying the cast net, who advanced slowly and indirectly toward a foraging or resting Long-billed Curlew. When the curlew was within reach (about $4 \mathrm{~m}$ away), the net was cast quickly toward the bird.

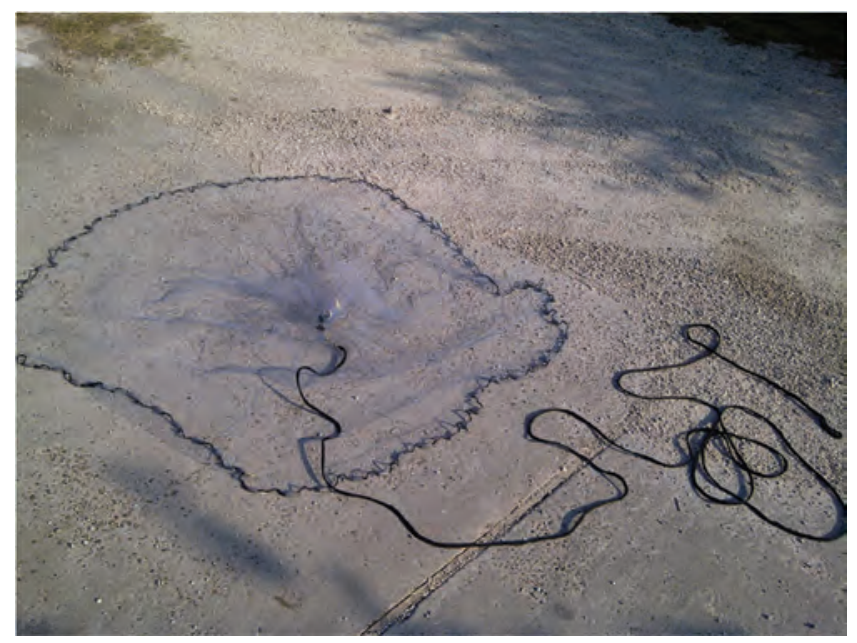

Figure 9. Cast net.

\section{Coda Netgun}

The Coda Netgun (Coda Enterprises, Inc., Mesa, Arizona) has been used successfully to capture shorebirds (Mittelhauser and others, 2006), wading birds (Herring and others, 2008), and other types of birds, including waterfowl (Mechlin and Shaiffer, 1980). The netgun uses blank rifle cartridges (light load, .308 caliber) to propel a square $4 \mathrm{~m} \times 4 \mathrm{~m}$ nylon net (tensile strength $18-36 \mathrm{~kg}$; mesh size $7 \mathrm{~cm} \times 7 \mathrm{~cm})$ and four stainless steel weights $(227 \mathrm{~g}$ each, one at each corner) over the bird(s) (fig. 10).

The netgun technique can be successful, yet there is a chance of injury or mortality to birds that are struck by a net

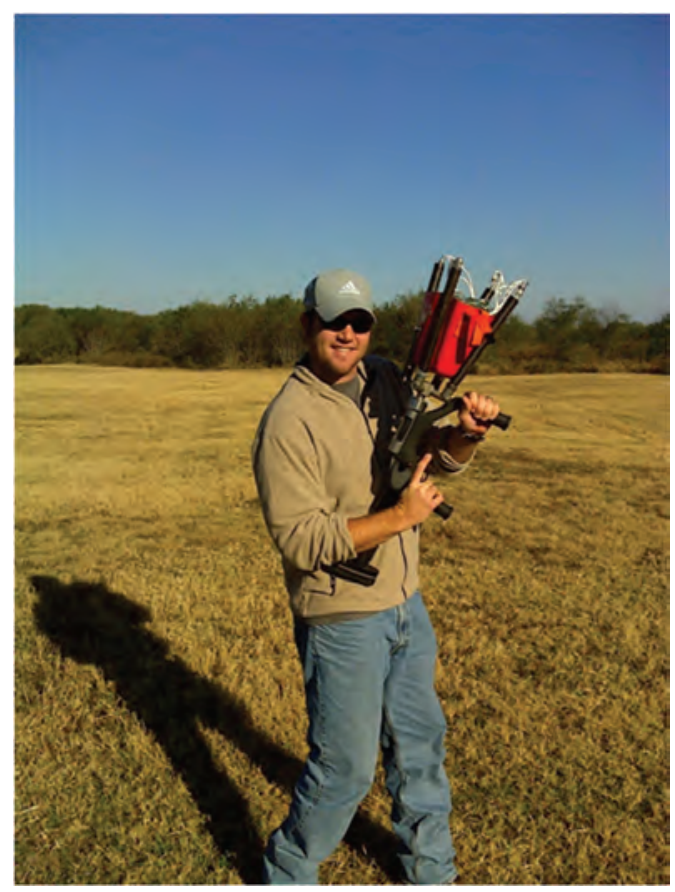

Figure 10. Coda Netgun.

weight. Mittelhauser and others (2006) reported that of 216 Purple Sandpipers (Calidris maritima) captured with the netgun, seven ( 3 percent) were killed and six ( 3 percent) were injured. However, in that study, researchers shot the net at large flocks of sandpipers in flight, which endangers birds located near the trajectory of the net's weighted corners. Padded weights (approximately $185 \mathrm{~g}$ each) are available as an option for reducing the risk of injury and mortality; however, the velocity of the nets and the effective distance for capture are reduced. In this study, Long-billed Curlews tended to forage widely in small, loose groups, which reduced the chance of injury from a netgun. Furthermore, individual birds frequently separated from other birds in the flock, and those birds were targeted when they were within the optimal range of the Netgun. Optimal conditions for firing the Netgun were when a bird was 5-15 m away (Herring and others, 2008) and within

$0-10 \mathrm{~m}$ above the ground. These conditions minimize injury from hitting the ground or from net tumbling. The Netgun was shot in a variety of ways, including pursuing the target while on foot, hiding behind objects, from an elevated platform, inside a slow-moving vehicle, and from a sitting position in the bed of a slow-moving pickup truck. In stationary situations, an assistant would herd the curlews toward the shooter's location to bring the bird within range of the Netgun.

\section{Super Talon Netgun}

The Super Talon Netgun (hereafter referred to as Talon) (Advanced Weapons Technology, Inc., La Quinta, California) is a hand-held netgun that uses compressed $\mathrm{CO}_{2}$ cartridges 


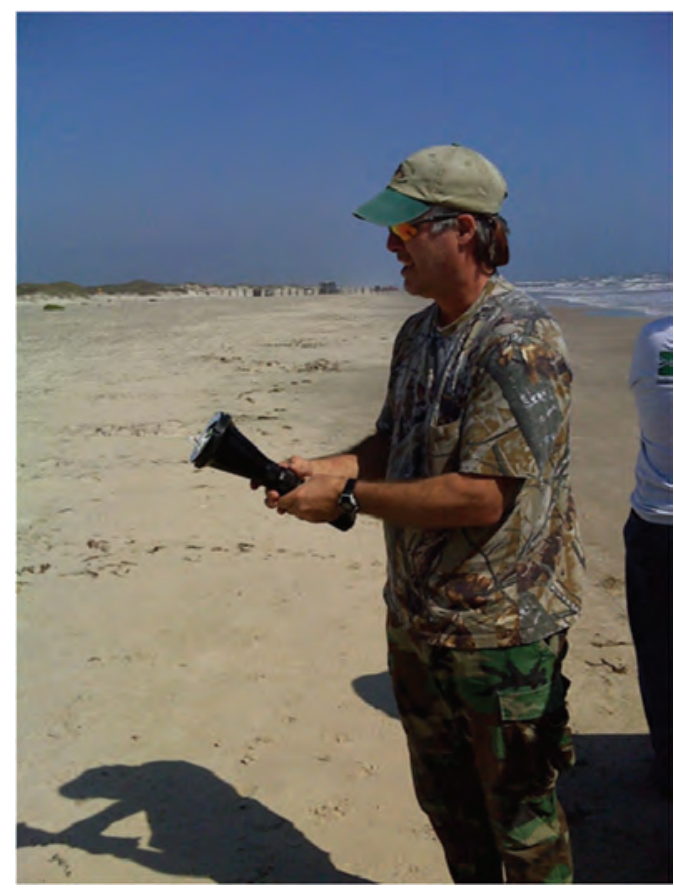

Figure 11. Super Talon Netgun.

to launch a circular net. The net was $4.8 \mathrm{~m}$ in diameter and launched at a speed of about 5 meters per second. The Talon was used on foot or from a vehicle, in the same manner as the Coda Netgun (fig. 11).

\section{Whoosh Net}

The whoosh net (Hawkseye Nets, Virginia Beach, Virginia) is a $7.6 \mathrm{~m} \times 4.8 \mathrm{~m}$ net with a mesh size of $6 \mathrm{~cm} \times$ $6 \mathrm{~cm}$ (fig. 12). The whoosh net was propelled by bungee cords

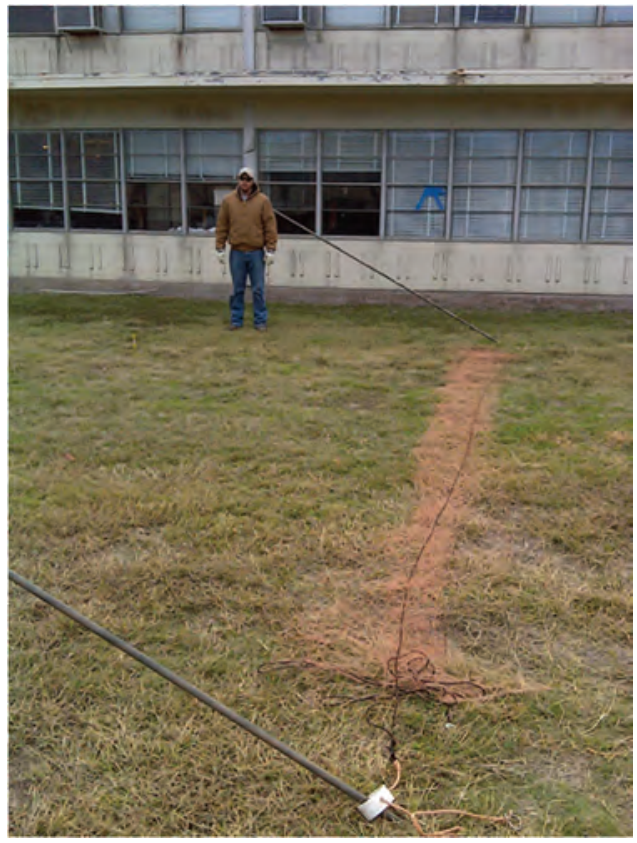

Figure 12. Whoosh net. that were released under tension by an observer holding a long trigger line. The release activated the net, which was quickly launched from the ground outward at a $45^{\circ}$ angle along two $2.5-\mathrm{m}$ guide poles, then dropped to cover the ground and capture the bird. The whoosh net was placed in fields within a curlew's projected path during foraging. The technique of driving, or herding, the curlews toward the target area of the whoosh net greatly increased the chances of a bird entering the target zone. Leafy tree trimmings were arranged along each side of the whoosh net to form a barrier, or drift fence, so that curlews would be more likely to enter the target area of the whoosh net. This technique worked best with three people: two people to gently drive the birds toward the net (and prevent them from walking around the net and drift fences) and a third person to pull the trigger line when one or more birds entered the target area.

\section{Decoys and Bait}

Curlew decoys (Knutson's Recreational Sales, Inc., Brooklyn, Michigan) were used in combination with noose ropes, bow nets, and the whoosh net to evaluate their ability to attract or provide confidence for Long-billed Curlews near a trap. One or more decoys were placed near the trap; any reactions to the decoys by Long-billed Curlews were noted. Earthworms and giant mealworms also were used in combination with noose ropes and bow nets to attract curlews to a trap. In the case of bow nets, bait was placed in the target area of a dummy bow net to habituate curlews' entrance to the small target area. Once a curlew began using the bait in the target area, a working bow net was set up in place of the dummy bow net. To avoid attracting other species of birds [such as meadowlarks (Sturnella spp.) and Killdeer (Charadrius vociferous)] that quickly devoured the bait before the curlews detected it, careful and sometimes fortuitous timing was required.

\section{Banding and Marking Birds}

Captured Long-billed Curlews were placed immediately in a cloth bag modified with a slit just large enough for the bill to protrude. This bag allowed the bird to be more relaxed, thereby easing its processing for handlers. Birds were then moved to the interior of a vehicle to insure against an inadvertent escape. Information recorded for each capture included date and time, county, trap type, vegetation type, weather, GPS location, and capture region. Two types of bands, USGS numeric aluminum bands (size 5 or 6 ) and two colored Darvic bands, were applied on the tibiotarsus (above the left "knee") (Gratto-Trevor, 2004). Band combinations were color-coded to differentiate between the two study regions. Birds to be captured in the northern region (Refugio, Nueces, and Kleberg counties) were designated with a sequence of orange over green over metal band, and birds to be captured in the southern region (Kenedy to Cameron 
counties) were designated with a sequence of orange over orange over metal band.

\section{Body Measurements}

Long-billed Curlews were weighed to the nearest $5 \mathrm{~g}$ with a Pesola spring scale $(1,000 \mathrm{~g} \mathrm{x} 10 \mathrm{~g})$. Digital calipers were used to measure total tarsus length to the nearest 0.1 millimeter $(\mathrm{mm})$. Straight-edge rulers were used to measure flattened wing length, exposed culmen length, culmen length (nostril-to-tip), and tail length to the nearest $1 \mathrm{~mm}$. Measurement techniques described in the North American Bander's Manual (Gratto-Trevor, 2004) and described in detail by Baldwin and others (1931) were applied unless otherwise indicated. The wing length was taken from the right wing at

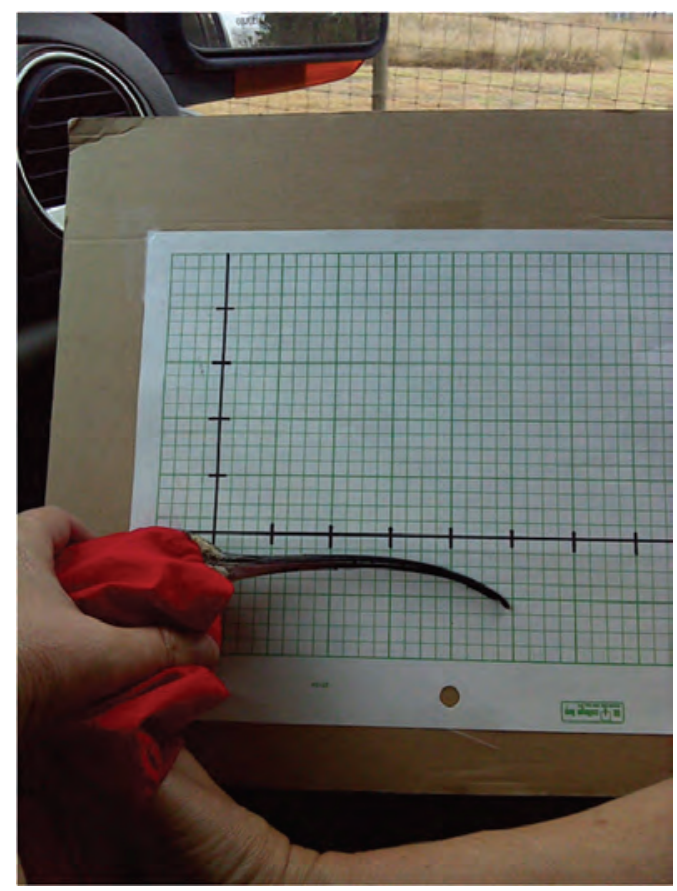

Figure 13. Method for measuring the curvature of Long-billed Curlew culmens.

the bend of the wing to the tip of the longest primary feather, while the wing was held flattened on top of a ruler. Exposed culmen length was measured from the point where feathers of the forehead ended to the tip of the bill. Nostril-to-tip culmen length was measured from the posterior end of the nostril opening to the tip of the bill (modified from the North American Bander's Manual). Photographs also were taken of the bird's culmen against a grid (graph paper mounted on cardboard) to measure the culmen curvature of Long-billed Curlews, and for possible use in differentiating between banded individuals (fig. 13). Tail length was measured from the tip of the pubis to the trailing edge of the longest tail feather. Tarsus length was measured from the base of the toes to the midpoint of the ankle joint.

After weighing and measuring captured curlews, each bird was examined for ectoparasites by searching areas of approximately $2 \mathrm{~cm}^{2}$ in the crown, upper leg, underwing, and vent regions. Ectoparasites often were concealed on the dark feather bases, so careful examination was required. Ectoparasites observed within these areas were collected, as were any ectoparasites that transferred to the researchers' hands. Collected ectoparasites were stored in 70-percent ethanol for later identification.

To ensure that banded birds were unharmed and did not suffer from capture myopathy (an often fatal condition caused by over-extension of muscles because of stress from capture and improper restraint) (Purchase and Minton, 1982; GrattoTrevor, 2004), Long-billed Curlews were placed in a holding box $(73 \mathrm{~cm} \times 66 \mathrm{~cm} \times 35 \mathrm{~cm})$ and observed for at least $15 \mathrm{~min}$ before being released in the vicinity of the capture. A supply of Diazepam was available for treatment of muscle myopathy (Piersma and others, 1991), but it was unnecessary for any of the birds that were captured. When the bird was standing and moving about in the box, the door was opened to allow the bird to walk out freely and fly away (fig. 14).

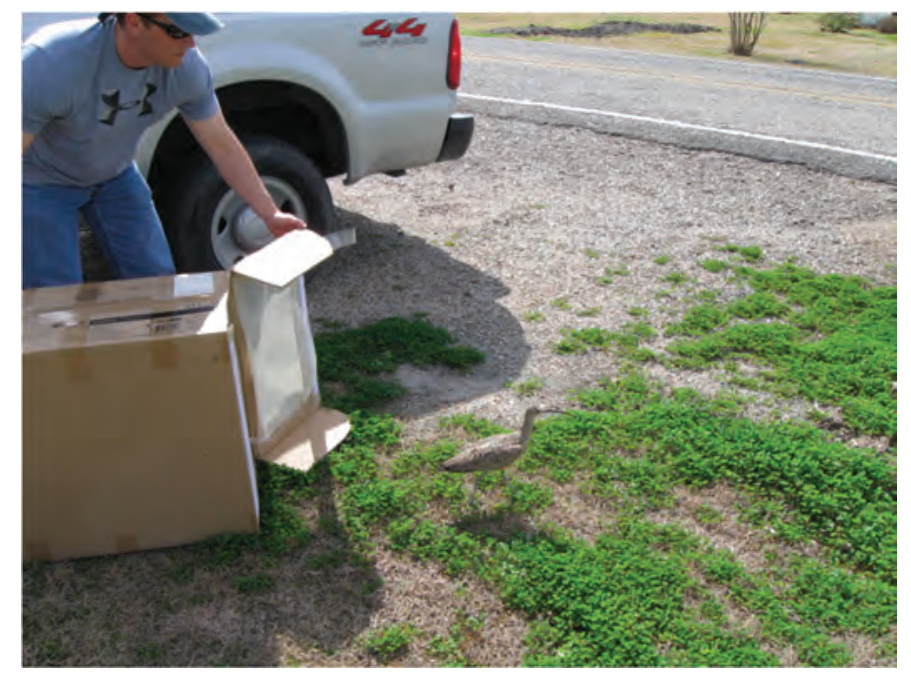

Figure 14. Release of Long-billed Curlew from a holding box.

\section{Movements and Migration Chronology}

Public and private lands were searched for Long-billed Curlews periodically by biologists, ranch managers, and birders throughout the community. Information on sightings of marked curlews also was solicited in the local media. GPS coordinate locations and behaviors of marked birds were recorded, as well as habitat type. All sightings were then placed in a resighting log for later reference. 


\section{Results and Discussion}

\section{Roost Site Monitoring}

Periodic monitoring of several nocturnal roost sites traditionally used by Long-billed Curlews indicated that these roosts seldom were used by birds during the winter of 2010-11 (table 1). Two traditional roost sites were visited at the saline lakes in Willacy and Hidalgo counties during the winter of 2010-11 (November 16, December 8, and January 25), but minimal curlew use was observed during the visits. Two birds were detected at East Lake on the evening of December 8, but no other Long-billed Curlews were observed. These results contrasted markedly from past tallies available from November-March at La Sal del Rey and East Lake. The average count of roosting Long-billed Curlews at La Sal del Rey during the 2002-03 winter was 1,703 (range= 1,3162,$014 ; \mathrm{n}=8$ surveys), and the mean 2003-04 winter count was 571 (range $=170-1,055 ; n=10$ surveys). Likewise, the $2003-$ 04 winter roost count on East Lake averaged 938 (range= 381-1,325; $\mathrm{n}=8$ surveys) Long-billed Curlews (B. Winton, U.S. Fish and Wildlife Service, Lower Rio Grande Valley National Wildlife Refuge, unpub. data). Clearly, the counts of Long-billed Curlews dropped precipitously in 2010-11 at these two sites that traditionally were used by relatively large numbers of curlews.

The sharp decline in curlew numbers was not matched by a decline in Sandhill Crane (Grus canadensis) numbers roosting at the salt lakes. Unlike Long-billed Curlews, Sandhill Cranes generally continued to roost in relatively large numbers at La Sal del Rey (550 in November 2010 and 577 in December 2010) and East Lake (230 in November, 262 in December, and 807 in January) during the winter of 2010-11, with the exception of January at La Sal del Rey, when no roosting cranes were observed.

During past winters, another traditional roost site that occurred along the upper reaches of Petronila Creek in Kleberg County was known to host hundreds of Longbilled Curlews (T. Langschied, Caesar Kleberg Wildlife Research Institute, oral commun., 2011). However, during the 2010-11 winter, no roosting birds were observed during two visits in early evening (December 1 and February 11). A third traditional roost site in the area at Aransas National Wildlife Refuge, in Aransas County, likewise demonstrated no use by Long-billed Curlews during the 2010-11 winter (B. Strobel, U.S. Fish and Wildlife Service, oral commun., 2011). A coastal roost site in Brazoria County near Freeport, Texas (north of the study area; not shown) was known to have held about 100 roosting Long-billed Curlews during previous winters (B. Ortego, Texas Parks and Wildlife Department, oral commun., 2011) but usually harbored less than 30 birds during the 2010-11 winter (D. Haley, Texas Parks and Wildlife Department, oral commun., 2011). This pattern of little to no use by curlews of traditional roost sites along the Texas coast suggests that either the numbers of curlews along the coast were down sharply in the winter of 2010-11 or that they had altered their use of nocturnal roost sites.

Several other roost sites were discovered, but even these were used by relatively modest numbers of birds (table 1). Flights of curlews (125 birds) were observed on the evening of January 6, 2011, as they descended toward a roost site along Los Olmos Creek, a western tributary of Baffin Bay (not shown) that serves as the boundary for Kleberg and Kenedy counties. The area was made up of shallow (less than or equal to $10 \mathrm{~cm}$ ) water and mudflats. As many as 150 Long-billed Curlews roosted intermittently during January and February in a plowed field near Bluntzer in western Nueces County, and 40-50 birds were observed attempting to roost in shallow (less than or equal to $10 \mathrm{~cm}$ ) water along the western shoreline of Oso Bay in Corpus Christi (Nueces County) in early March. The Oso Bay birds may have been migrants, as they startled easily and flushed for unknown reasons, relocating along the far western shoreline of Oso Bay.

An original objective for this part of the project was to collect data describing physical characteristics of roost sites. This objective proved impractical. Traditional roost sites at known locations had minimal usage by Long-billed Curlews during the winter of 2010-11, and the few new roost sites located had either access issues or only intermittent use by curlews.

Table 1. Locations, habitat types, and use by Long-billed Curlews of roost sites monitored in southern Texas during the winter of 2010-11.

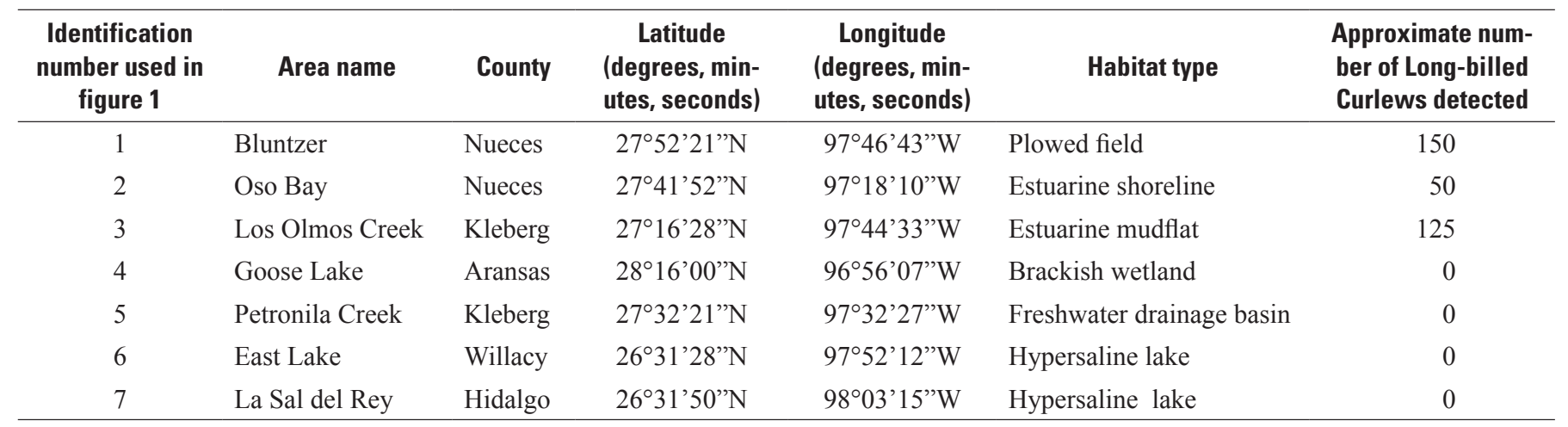


This short study demonstrated that the use of nocturnal roost sites by Long-billed Curlews in winter is far more dynamic than has been assumed previously. Nonuse of traditional roost sites through the winter, intermittent occupancy of a roost site in a tilled agricultural field, and movement of curlew flocks among alternative roost sites within the same evening all point to a pattern of complex movements among multiple roost sites by curlews that cannot be understood easily. Greater insights into movements and roost site use could be gained by following curlews marked with satellite transmitters.

\section{Public Outreach}

The willingness of the public in this region to participate in wildlife research proved to be valuable to the Long-billed Curlew project. Outreach efforts resulted in 90 separate reports of Long-billed Curlews from the community (table 2). Most reports were made by email or telephone, in approximately equal proportions. There were 67 people (including four

Table 2. Numbers of locations and reports of Long-billed Curlew sightings by habitat type in response to public outreach methods.

\begin{tabular}{lcc}
\hline \multicolumn{1}{c}{ Habitat type } & $\begin{array}{c}\text { Number of } \\
\text { locations } \\
\text { reported }\end{array}$ & $\begin{array}{c}\text { Number of } \\
\text { reports }\end{array}$ \\
\hline Urban or suburban grasslands & 48 & 74 \\
Beach & 1 & 4 \\
Coastal marsh & 2 & 3 \\
Agricultural & 3 & 5 \\
Estuary open water & 3 & 3 \\
Estuary tidal mudflats & 1 & 1 \\
Total & $\mathbf{5 8}$ & $\mathbf{9 0}$ \\
\hline
\end{tabular}

anonymous callers who were counted as four different people) that contacted the USGS to report curlews. Verification was made for 65 percent of the reports; other sites near Premont (not shown) and Laguna Madre (between the mainland and Padre Island; not shown) could not be verified because sites were inaccessible or in areas far from Corpus Christi. Of the 58 different locations reported with Long-billed Curlews, 31 (53 percent) were curlew locations previously unknown to project personnel.

Limited research has been conducted on inland habitat use by Long-billed Curlews in southern Texas, although Olalla-Kerstupp (2010) quantified curlew use of inland habitats in northeastern Mexico. Most of Long-billed Curlew sightings from the public and colleagues occurred in the area within and surrounding Corpus Christi; however, a few sightings were reported as far south as the Rio Grande Valley (not shown; Cameron, Hidalgo, and Willacy counties), as far inland as Jim Wells County, and as far north as Calhoun County (table 2; fig. 1). Among the observed vegetation types used by curlews, the proportion of used habitats was skewed strongly toward urban grasslands. Of 58 different locations reported, 48 (83 percent) were urban grasslands (residential yards or empty mowed lots adjacent to businesses) (table 2). This apparent pattern of habitat use is most likely biased toward more urban areas where densities of potential observers are greater. In comparison, Brush (1995) documented that Long-billed Curlews in the Laguna Madre of Texas (not shown) used shallow mudflats exclusively, but he also noted that curlews moved between the coastal flats and unknown inland destinations. The habitats most frequently used by foraging curlews in the Chihuahuan Desert (not shown) in northeastern Mexico were agricultural lands, fallow fields, and prairie dog colonies (Olalla-Kerstupp, 2010).

By far, the most productive method of soliciting information from the public was the use of the major local newspaper, the Corpus Christi Caller-Times. Two articles produced numerous phone calls from the community. The first article, titled "Look - don't touch - and help count the curlews" appeared January 6, 2011, in the Outdoors section of the newspaper (Sikes, 2011). The second article, appearing February 7, 2011, was the weekly column titled "Bird watch" in which the columnist requested her readers to send information on Long-billed Curlews to the USGS.

The use of TexBirds, a popular online list serve for birding enthusiasts in Texas, was successful in collecting reports by email for Long-billed Curlews inside and outside of the Corpus Christi area. It is unknown how many reports were direct results from the bulletin board flier, birding club newsletter, or the television interview.

The public outreach objective of this project was successful beyond expectations. However, the generous response by the public was not unprecedented. A similar outreach program in the Corpus Christi area in 2001 resulted in an increase of Burrowing Owl (Athene cunicularia) sightings by 68 percent from the previous winter (Woodin and others, 2007). Corpus Christi has held the title of the "Birdiest City in America" since 2003 (Coastal Bend Audubon Society, 2010), and southern Texas attracts many nature enthusiasts, especially during the winter, when its mild climate attracts visitors from the northern U.S. and Canada. Using this large group of "birders" in southern Texas yielded a greater return on a relatively small investment of effort.

\section{Capture and Banding}

\section{Capture Techniques}

Previous efforts to capture Long-billed Curlews on their winter grounds were limited to a single study (OlallaKerstupp, 2010). Seven Long-billed Curlews were captured during the winter of 2010-11 (table 3). Four of the six capture techniques evaluated were successful in capturing at least one curlew each: Coda Netgun (4), noose ropes (1), bow net (1), and whoosh net (1). Of the four successful capture techniques, 
Table 3. Dates, locations, and techniques used in capture of Long-billed Curlews in southern Texas, 2010-11.

\begin{tabular}{llccl}
\hline \multicolumn{1}{c}{ Date } & County & $\begin{array}{c}\text { Latitude } \\
\text { (degrees, minutes, } \\
\text { seconds) }\end{array}$ & $\begin{array}{c}\text { Longitude } \\
\text { (degrees, minutes, } \\
\text { seconds) }\end{array}$ & Trap type \\
\hline December 30, 2010 & Nueces & $27^{\circ} 40^{\prime} 03^{\prime \prime} \mathrm{N}$ & $97^{\circ} 21^{\prime} 48^{\prime \prime} \mathrm{W}$ & Noose rope. \\
January 3, 2011 & Nueces & $27^{\circ} 52^{\prime} 49^{\prime \prime} \mathrm{N}$ & $97^{\circ} 46^{\prime} 38^{\prime \prime} \mathrm{W}$ & Baited bow net. \\
January 29, 2011 & Nueces & $27^{\circ} 52^{\prime} 42^{\prime \prime} \mathrm{N}$ & $97^{\circ} 46^{\prime} 35^{\prime \prime} \mathrm{W}$ & Coda Netgun. \\
February 18, 2011 & Refugio & $28^{\circ} 23^{\prime} 18^{\prime \prime} \mathrm{N}$ & $96^{\circ} 50^{\prime} 19^{\prime \prime} \mathrm{W}$ & Coda Netgun. \\
February 23, 2011 & Kleberg & $27^{\circ} 27^{\prime} 01^{\prime \prime} \mathrm{N}$ & $97^{\circ} 17^{\prime} 10^{\prime \prime} \mathrm{W}$ & Coda Netgun. \\
February 23, 2011 & Kleberg & $27^{\circ} 27^{\prime} 17^{\prime \prime} \mathrm{N}$ & $97^{\circ} 17^{\prime} 03^{\prime \prime} \mathrm{W}$ & Coda Netgun. \\
March 2, 2011 & Nueces & $27^{\circ} 40^{\prime} 06^{\prime \prime} \mathrm{N}$ & $97^{\circ} 21^{\prime} 50^{\prime \prime} \mathrm{W}$ & Whoosh net. \\
\hline
\end{tabular}

the Coda Netgun had the highest rate of capture per unit of effort $(0.31 ; 4$ curlew captures per 13 days of trapping effort). The bow net and whoosh net had capture rates of 0.17 ( 1 capture per 6 days of effort) and 0.14 ( 1 capture per 7 days of effort), respectively. Of the four successful techniques, the noose ropes were the least efficient with a capture rate of 0.07 ( 1 capture per 15 days of effort), although noose ropes in this study were undergoing continual modification. No curlews were captured with a cast net (1 day of effort) or the Talon (3 days of effort).

There were four curlews captured with the Coda Netgun, all from a vehicle serving as a blind. In one case, the vehicle was stationary, and the curlew walked within range of the Netgun without herding. For the other three captures, the vehicle was driven slowly alongside the curlews within range of the Netgun (as much as $\sim 30 \mathrm{~m}$ ). The driver stopped the vehicle after the Netgun was fired. With the approach of a vehicle, the curlews would move slowly away from the road, but in some cases, one or more remained within range of the Netgun. Although many attempts were made at herding curlews toward a shooter in a parked vehicle, the curlews usually avoided the vehicle, and such efforts were never successful in capturing a bird.

An important aspect to successfully capturing a bird with the Coda Netgun is the loading of the net into the basket to ensure that the net opens fully each time it is fired. After trying many different methods of folding, only one method allowed the net to open fully every time. This method required three people. Two people held the net fully outstretched horizontally, with one weight in each hand, while a third person held the basket of the Netgun under the outstretched net and began feeding the net into the basket, starting with the center of the net, then gathering the sides and feeding evenly into the basket. The two net holders would walk slowly toward the basket as the net went in, until only the four corners and weights were outside the basket. The weights were then inserted into the proper barrels, taking care not to twist or cross the cords attached to the weights.

Use of noose ropes resulted in one capture of a Longbilled Curlew. A second curlew was ensnared briefly by a noose rope, but the monofilament detached from the rope, freeing the bird from the rope and weights. This bird was observed a few minutes later unharmed and foraging normally with the flock with the monofilament noose still attached to its leg.

Although curlews can be captured with noose ropes or mats, as demonstrated by Olalla-Kerstupp (2010) and this study, we did not achieve the exceptional success with noose mats that Mehl and others (2003) reported for capture of small-bodied shorebirds [for example, Snowy Plovers (Charadrius alexandrinus)]. Despite attempts to camouflage and conceal the rope and monofilament, most curlews walked around or flew over the ropes when encountering the ropes in their path. When a curlew did walk over a noose rope, its toes rarely caught a noose, or the noose did not close quickly or efficiently enough to capture the bird. However, effectiveness was increased by (1) using straws to hold monofilament nooses more erect, (2) limiting their deployment to completely overcast days, and (3) limiting deployment to fields with sufficient thatch and grass to conceal noose rope outlines. Olalla-Kerstupp (2010) captured five wintering Long-billed Curlews using noose mats in Mexico. Olalla-Kerstupp's success rate may have been higher for several reasons. Limited water sources in northeastern Mexico likely resulted in greater concentrations of curlews, as well as more concentrated capture efforts, than was possible in southern Texas. If noose ropes or carpets are considered for future capture efforts, it is important to understand that they were time-consuming to construct, difficult to transport, susceptible to malfunctions, and their efficacy will vary with substrate conditions.

Bow nets traditionally are used with live vertebrate bait for capturing raptors (Bryan, 1988; Proudfoot and Jacobs, 2001; Barclay, 2008). There was one successful curlew capture by baiting the bow net with giant mealworms. This capture required approximately 3 weeks of preparation before the capture to induce the curlews to come to the trap. Two challenges had to be overcome to capture a curlew with the bow net. The first challenge was to time placement of bait with the movements of the foraging curlews to ensure the curlews would discover the bait before other bird species discovered the bait. Herding curlews in the direction of the bow net was sometimes helpful in this effort. The second challenge was 
to repeat this enough times (at least twice) for the birds to associate food with the bow net.

About an hour before capturing the Long-billed Curlew with the bow net, one curlew was observed defending the bow net from conspecifics. Killdeer also were observed defending bait at the bow nets against conspecifics. Once the armed bow net was put in place, a curlew was captured quickly (within 10-15 minutes). However, later attempts to repeat the capture technique failed, probably because a period of 2 weeks elapsed before attempting to retrain the birds to come to the bow net again. A few more near captures of other Long-billed Curlews did occur, but the birds were too near the edge of the capture area and at risk of injury from the descending frame upon the release of the bow net. If a trapper is able to spend several days consecutively at a single location, this technique can work, but it requires a large investment of time and a substantial supply of bait (along with proper storing and feeding of the bait). Giant mealworms were more advantageous than earthworms because of their lower cost and convenient feeding and storage requirements. It is unknown if Long-billed Curlews had a preference between the two types of bait.

Shorebirds and other bird species have been successfully caught using whoosh nets (for example, Kenward and others, 2004; Cresswell and others, 2007). One curlew was captured using the whoosh net. Several attempts to capture curlews with this technique failed for one of two reasons: the curlews feeding in the area relocated to another area before the whoosh net assembly was completed (set-up time is about 30 minutes), or the curlews could not be herded into the target area of the net. The successful capture of a curlew using the whoosh net occurred after the net had been set up in a field regularly used by curlews. Drift fence material (made of tree clippings) also was put in place ahead of time. When the curlews arrived to forage, only 5-10 minutes of preparation were needed. Leaving the net and poles in place for several days at a time requires landowner permission and puts the equipment at risk of theft or vandalism; however, the curlews will habituate to the presence of the net, and the trappers can respond quickly to the arrival of Long-billed Curlews.

The Talon was tested multiple times in urban environments and on the beach. It was fired from a slowmoving vehicle, approaching the curlew on foot, and once from a blind (from behind a mound of earth). This netgun was better suited to urban work because it was smaller and quieter than the Coda Netgun, however, it failed to capture a curlew. In general, the Talon was determined to be under-powered, and it performed poorly in windy conditions (such as on the beach). However, with modifications such as adding heavier weights and increasing propulsion, this technique might be effective for capturing Long-billed Curlews. Even without these modifications, the Talon may still be successful at close range (approximately 3-5 $\mathrm{m}$ or less), in little or no wind, and with wintering Long-billed Curlews that have become habituated to humans and vehicles in urban and suburban environments. No publications were identified that reported use of this tool for wildlife, although the company notes its use for a variety of species.

Many flocks of wintering Long-billed Curlews were habituated to human presence and tolerated close approaches by humans. This was especially true in city parks or empty neighborhood lots where walkers, joggers, or home gardeners shared the space with wintering Long-billed Curlews. This prompted the testing of a cast net as a capture technique. Cast nets have been used successfully in capturing scavenging sea birds over chum (Gibson and Sefton, 1959; Bugoni and others, 2008). However, the speed of the net's approach in the air was much too slow to catch a Long-billed Curlew. Despite several close approaches and accurate throws, the curlew always flew away before the cast net could reach it. Even birds that appeared to be resting were wary enough to escape this trap easily.

Although hunters of the 19th and early 20th centuries considered Long-billed Curlews to be wary, curlews were easily drawn into shooting range with decoys (Wickersham, 1902; Forbush, 1916; Oring, 2006). Decoys were tested in combination with noose ropes, bow nets, and the whoosh net. Results varied, but in general, the birds initially were attracted to the decoys and would land 10-15 m from them. However, after spending a few seconds in the company of a decoy, the curlews became alarmed and left. Since the objective of the decoys in the capture evaluation was not only to attract the curlews to a site, but also to give them confidence around the traps, the decoys proved to be of little use.

The potential for injury to birds exists with all capture endeavors. Injury can result from net weights striking the bird, feather entanglement in nets, and excessive stress to the bird during field processing. Of the seven Long-billed Curlews captured during this project, using four different capture techniques, none were injured. No individual appeared to suffer from capture myopathy, and all were released by way of a "soft" release from the holding box. After their release, six of the seven were sighted foraging normally with other curlews. The banded curlew that was not resighted was the last captured of the season, and close to the time curlews were departing the region. In addition, no curlews were injured during any of the failed capture attempts.

Some additional capture methods that previously have been used to capture shore birds were considered but not used in this study; these included mist nets, walk-in traps, drop nets, and rocket nets. Previous studies had proven mist nets were not successful in capturing curlews and other shorebirds during the day because the birds see the nets and successfully avoid them (Gabbard and others, 2001; K.C. Jensen, South Dakota State University, oral commun., 2010). Mist nets have proven more successful at night with roosting shorebirds (Gabbard and others, 2001; Gratto-Trevor, 2004), but capturing Long-billed Curlews at night was precluded in order to avoid disturbance and minimize the potential for injury to large numbers of curlews. Walk-in traps and drop nets were not used because of the reluctance of Long-billed Curlews to walk inside or under structures (M. Colwell, Humboldt 
State University, oral commun., 2010; authors' observations). Finally, although rocket nets were available, aggregations of sufficient numbers of curlews were not present, except in urban areas where firing rocket nets was impractical.

\section{Banding and Marking Birds}

Seven Long-billed Curlews were captured in the northern counties and fitted with size 5 bands (fig. 15). The northernmost capture was in Refugio County, and the two southernmost captures were in Kleberg County. All others were caught in Nueces County. No curlews were captured in Kenedy or Cameron counties to the south.

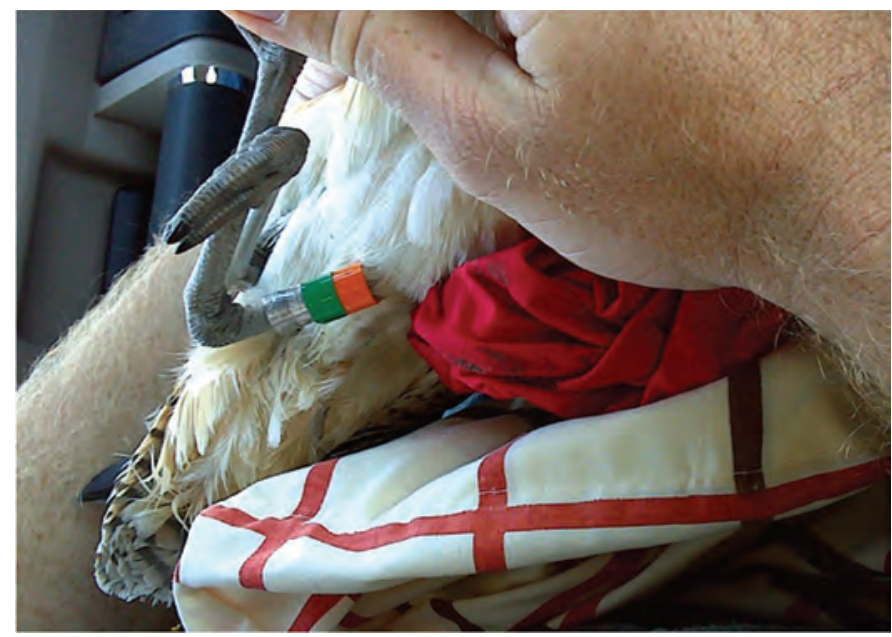

Figure 15. Band types and colors placed on Long-billed Curlews.

\section{Body Measurements}

Available data on body mass of Long-billed Curlews are generally dated and restricted mostly to breeding birds or young [see appendix in Dugger and Dugger (2002)]. The mean body mass for Long-billed Curlews (table 4) captured was $518 \mathrm{~g}(\mathrm{n}=7)$. This was notably smaller than mean masses for breeding curlews reported by Johnsgard (1981), with averages of $640 \mathrm{~g}$ (range $=445-792 \mathrm{~g}$ ) for males and $757 \mathrm{~g}$ (range $=630-951 \mathrm{~g}$ ) for females. Although average mass was less than other studies (see Dugger and Dugger 2002), structural size of the curlews seemed to be similar. Wing measurements collected for this study averaged $273 \mathrm{~mm}$ (range $=262-279 \mathrm{~mm}$ ), which was similar to Grinnell's (1921) collections of $270 \mathrm{~mm}$ (range $=248-291 \mathrm{~mm})$, although it is important to note that measurement techniques could be slightly different. Uncertainties in ability to accurately age and sex the captured curlews in this study prevented assignment to age or sex categories.

Ectoparasites, such as feather lice (Columbicola spp.), were found on three of the seven individuals. The largest number of parasites collected from an individual was eight, which were collected from the smallest and last-captured individual. Lice have been reported previously on Long-billed Curlews in winter (Wilson, 1937; Butler and Pfaffenberger, 1981).

\section{Movements and Migration Chronology}

Resightings of banded Long-billed Curlews were obtained 22 times. Although many of the resightings could not be linked to specific individuals, generalizations of movements can be made. All resightings were in the same area of a capture, often within a flock displaying "normal" behavior. These resightings started the same day of initial capture, were within $2 \mathrm{~km}$ of capture site, and occurred 1 hour to 53 days after release of a marked bird in that area. This suggests that capturing and banding of individuals within a flock was not necessarily enough of a disturbance to make them leave the area.

In one instance, a banded Long-billed Curlew, which was the only one banded at that time, was sighted three times within a week with a small flock at the same location where it had been banded. Then, after the arrival of a strong cold front, no banded curlews were recorded in those foraging locations for the remainder of the wintering season, although unmarked curlews were observed foraging in the general area.

The last sighting of a banded curlew was reported on March 25, 2011, on Padre Island National Seashore beach. The migration chronology is similar to that of curlews in

Table 4. Measures of body mass and structural size of Long-billed Curlews captured and banded in southern Texas, 2010-11.

\begin{tabular}{|c|c|c|c|c|c|c|c|}
\hline Band number & Date & $\begin{array}{c}\text { Body mass } \\
\text { (in grams) }\end{array}$ & $\begin{array}{c}\text { Tail length } \\
\text { (in millime- } \\
\text { ters) }\end{array}$ & $\begin{array}{c}\text { Culmen } \\
\text { (exposed, in } \\
\text { millimeters) }\end{array}$ & $\begin{array}{c}\text { Culmen } \\
\text { (nostril-tip, in } \\
\text { millimeters) }\end{array}$ & $\begin{array}{c}\text { Tarsus length } \\
\text { (in millime- } \\
\text { ters) }\end{array}$ & $\begin{array}{l}\text { Wing length } \\
\text { (flat, in millime- } \\
\text { ters) }\end{array}$ \\
\hline $1095-49076$ & December 30, 2010 & 495 & 115 & 124 & 108 & 78.0 & 262 \\
\hline $1095-49072$ & January 3, 2011 & 510 & 125 & 125 & 108 & 75.8 & 284 \\
\hline $1095-49075$ & January 29, 2011 & 525 & 97 & 120 & 104 & 79.8 & 265 \\
\hline $1095-49080$ & February 18, 2011 & 470 & 102 & 120 & 102 & 86.7 & 279 \\
\hline $1095-49073$ & February 23, 2011 & 670 & 101 & 170 & 138 & 94.1 & 276 \\
\hline $1095-49074$ & February 23, 2011 & 515 & 114 & 122 & 105 & 84.4 & 278 \\
\hline $1095-49078$ & March 2, 2011 & 440 & 109 & 110 & 92 & 77.0 & 264 \\
\hline Mean & & 518 & 109 & 127 & 108 & 82.3 & 273 \\
\hline
\end{tabular}


northeastern Mexico, where Olalla-Kerstupp (2010) reported that two birds with transmitters departed the winter range on March 19 and March 24, 2010.

All resightings of banded curlews were reported in the same vegetation types as original capture sites. This includes the two individuals that were captured in the wrack line of the beach, as well as the five captured in groomed lots in urban settings.

\section{Conclusions and Recommendations for Future Studies}

This 1-year field study revealed that roost site locations and their use by Long-billed Curlews can be more fluid temporally than had been understood previously. Use of winter roost sites by Long-billed Curlews and bird movements among roost sites and foraging areas needs further investigation.

Ideally, monitoring curlews for the full winter and subsequent spring migration phases would provide insight to regional habitat needs; information which would ultimately contribute to management decisions. Because of the large landscape scale presented by the coastal plains of Texas, Long-billed Curlews could potentially move along the Texas coast and into northeastern Mexico, where large numbers also are known to exist. Further study of Long-billed Curlew winter movements, roost site use, and migration chronology may be accomplished most effectively by data acquisition from curlews equipped with satellite transmitters.

The public outreach exercise yielded gratifying public response. Many residents of coastal Texas were genuinely eager to participate in the monitoring and conservation of curlews. Most curlew observations reported by the public were birds in urban areas. This pattern remained consistent even for small towns in rural areas, where citizens reported Long-billed Curlews in undeveloped residential lots, schoolyards, and golf courses. Clearly, a substantial portion of the winter population of Long-billed Curlews in coastal Texas is occupying urban areas. The use of urban habitats, altered habitats in rural areas (farm fields and hay pastures), and largely unaltered coastal marshes merits further investigation.

Long-billed Curlews were captured without injury with a variety of techniques. The Coda Netgun was most efficient in capturing birds in urban settings and on the beach, although it had some limitations. Application of other capture techniques was made relatively inefficient by the neophobic responses of Long-billed Curlews to the introduction of novel items to their foraging areas. This neophobic reaction to noose ropes, nets, and traps of all types meant that these capture techniques had to be accompanied by patience and a trial-and-error approach. The ability to choose from a mix of techniques to match circumstances presented by curlews foraging in a variety of habitats is paramount for maximizing capture success. Despite the apparent weakness of some techniques in this study, those techniques may warrant further investigation and refinement for application in particular circumstances.

The body masses of the seven curlews captured were lower than those reported in previous studies (Dugger and Dugger, 2002). In fact, they were near the minimum body mass reported in the literature. Because the variation in body mass in winter is linked to fat content of the individual birds (for example, Rappole, 1995; Moon and Haukos, 2009), curlews measured in this study likely were extremely lean. Wintering shorebirds are often lighter than breeding and migratory birds and, in the absence of age and sex information on the individuals, further speculation about relative mass is precluded. Further research is warranted to obtain adequate sample sizes to evaluate variation in body mass among years and across wintering areas (for example, coastal Texas, northern Mexico, and western populations) and to compare between ages and sexes.

Adequate information about movements and migration chronology of wintering Long-billed Curlews is not available, and thus, are not well understood (Fellows and Jones, 2009; Dugger and Dugger, 2002). Two birds from Mexico that were equipped with satellite transmitters moved northward on spring migration through western Texas and eastern New Mexico (Olalla-Kerstupp, 2010), with one of these birds migrating as far north as Canada. In some cases, curlews do not depart winter grounds. Oberholser (1974) and Rappole and Blacklock (1994) noted that Long-billed Curlews regularly spend the summer along the Texas coast, and one of four wintering curlews with attached transmitters did not depart Mexico (Olalla-Kerstupp, 2010). Long-billed Curlews that remain in coastal Texas and northeastern Mexico in the summer rarely breed in the region (Oberholser, 1974), although intensive searching for young has been conducted (G. Perrigo, Texas A\&M - Kingsville, oral commun., 2011).

Reduced numbers of curlews were evident during the study, possibly because of dry conditions, which also may have altered bird use of roost sites. Traditional roost sites essentially were unused by curlews for the winter, but small numbers of curlews did intermittently use other roosts. In addition, at least some curlews regularly used mowed lots, golf courses, and public parks within urban and suburban zones, a phenomenon widely recognized locally but mentioned rarely in published literature (Fellows and Jones, 2009). Curlews foraged in a variety of habitats, including grassy urban environments, agriculture areas, beaches along the Gulf of Mexico, and salt marshes affected by tides. It is unknown how use of these divergent habitat types is related to the regular occurrence of nonbreeding summer residents on the winter range; nor is it known where spring migrants settle for breeding. This seemingly confusing array of facts could become especially important in light of future regional climate projections of increased temperature and increased moisture deficiencies (Norwine and Kuruvilla, 2007) in southern Texas. Wetland and grassland habitats are important for curlews for secure roosting and foraging habitats (Dugger and Dugger, 2002; Mathis and others 2006; this study), and their breeding 
distribution has been documented to be related to temperature and precipitation (Price, 1995). Hence, potential changes in climate and habitat quality may affect winter survival and body condition of Long-billed Curlews. This pilot study exposed some interesting questions that require further investigation, so migratory bird and land managers have more information for decisions about the conservation of this species.

\section{References Cited}

Baldwin, S.P., Oberholser, H.C., and Worley, L.G., 1931, Measurements of birds: Scientific Publications of the Cleveland Museum of Natural History, Cleveland, Ohio, v. 2, 165 p.

Barclay, J.H., 2008, A technique for nighttime trapping of Burrowing Owls with a bow net: Journal of Raptor Research, v. 42 , p. $142-148$.

Brush, T., 1995, Habitat use by wintering shorebirds along the lower Laguna Madre of South Texas: Texas Journal of Science, v. 47, p. 179-190.

Bryan, J.R., 1988, Radio controlled bow-net for American Kestrels: North American Bird Bander, v. 13, p. 30-32.

Buchanan, M., 2011, Historic January tornado in south Texas-January 9th, 2011 squall line: Corpus Christi, Tex., South Texas Weather Journal, Spring 2011, p. 8-9.

Bugoni, L., Neves, T.S., Peppes, F.V., and Furness R.W., 2008, An effective method for trapping scavenging seabirds at sea: Journal of Field Ornithology, v. 79, p. 308-313.

Butler, W.F., and Pfaffenberger, G.S., 1981, Notes on parasites of the Long-billed Curlew, (Numenius americanus), from eastern New Mexico: Journal of Wildlife Diseases, v. 17, p. $537-538$.

Clarke, J. 2006, Reproductive ecology of long-billed curlews breeding in grazed landscapes of western South Dakota: Brookings, S. Dak., South Dakota State University, M.S. thesis, $94 \mathrm{p}$.

Coastal Bend Audubon Society, 2010, South Texas birding on TV: The Brown Pelican, The Newsletter of the Coastal Band Audubon Society, September/October 2010, 8 p.

Cresswell, W., Lind, J., Quinn, J.L., Minderman, J., and Whitfield, D.P., 2007, Ringing or colour-banding does not increase predation mortality in redshanks Tringa tetanus, Journal of Avian Biology, v. 38, p. 309-316.

Crosswhite, F.S., 1980, Dry country plants of the south Texas plains: Desert Plants, v. 2, p. 141-179.
Danufsky, T., and Colwell, M.A., 2003, Winter shorebird communities and tidal flat characteristics at Humboldt Bay, California: Condor, v. 105, p. 114-129.

Dugger, B.D., and Dugger, K.M., 2002, Long-billed Curlew (Numenius americanus) in Poole, A., ed., The Birds of North America, no. 628: Ithaca, N.Y., The Cornell Lab of Ornithology, $27 \mathrm{p}$.

Fellows, S.D., and Jones, S.L., 2009, Status assessment and conservation action plan for the Long-Billed Curlew (Numenius americanus): U.S. Department of the Interior, Fish and Wildlife Service, Biological Technical Publication, FWS/BTP-06012-2009, Washington, D.C., 102 p.

Forbush, E.H., 1916, A history of the game-birds, wild-fowl, and shore birds of Massachusetts and adjacent states ( $2 \mathrm{~d}$ ed): Boston, Massachusetts State Board of Agriculture, $636 \mathrm{p}$.

Gabbard, C., Sprandel, G., and Cobb, D., 2001, Home range analyses of shorebirds wintering along the Gulf of Mexico, Florida, USA: Wader Study Group Bulletin, v. 96, p. 79-85.

Gibson, J.D., and Sefton, A.R., 1959, First report of the New South Wales Albatross Study Group: Emu, v. 59, p. 73-82.

Gittinger, M., and Buchanan, M., 2011, Historic ice stormNWS Corpus Christi, Tex.: South Texas Weather Journal, Spring 2011, p. 1-2.

Gould, F.W., Hoffman, G.O., and Rechenthin, C.A., 1960, Vegetational areas of Texas: College Station, Tex., Texas A\&M University, Texas Agricultural Experiment Station, Leaflet No. 492.

Grantham, M., 2011, A review of the 2010-2011 cool season-Corpus Christi, Tex.: South Texas Weather Journal, Spring 2011, p. 4.

Gratto-Trevor, C.L., 2004, The North American Banders Manual for banding shorebirds (Charadriiformes, suborder Charadrii): Point Reyes Station, Calif., The North American Banding Council, 45 p.

Grinnell, J., 1921, Concerning the status of the supposed two races of the Long-billed Curlew: Condor, v. 23, p. 21-27.

Herring, G., Gawlik, D.E., and Beerens, J.M., 2008, Evaluating two new methods for capturing large wetland birds: Journal of Field Ornithology, v. 79, p. 102-110.

Hicklin, P.W., Hounsell, R.G., and Finney, G.H., 1989, Fundy pull trap - a new method of capturing shorebirds: Journal of Field Ornithology, v. 60, p. 94-101.

Johnsgard, P.A., 1981, Plovers, sandpipers, and snipes of the world: Lincoln, Neb., University of Nebraska Press, 493 p. 
Jones, S.L., Nations, C.S., Fellows, S.D., and McDonald, L.L., 2008, Breeding abundance and distribution of Long-billed Curlews (Numenius americanus) in North America: Waterbirds, v. 31, p. 1-14.

Kenward, B., Rutz, C., Weir, A.A.S., Chappell, J., and Kacelnik, A., 2004, Morphology and sexual dimorphism of the New Caledonian Crow Corvus moneduloides, with notes on its behaviour and ecology: Ibis, v. 146, p. 652-660.

Leeman, L.W., Colwell, M.A., Leeman, T.S., and Mathis, R.L., 2001, Diets, energy intake, and kleptoparasitism of nonbreeding Long-billed Curlews in a northern California estuary: Wilson Bulletin, v. 113, p. 196-203.

Mathis, R.L., Colwell, M.A., Leeman, L.W., and Leeman, T.S., 2006, Long-billed Curlew distributions in intertidal habitats: scale-dependent patterns: Western Birds, v. 37, p. 156-168.

Mechlin, L.M., and Shaiffer, C.W., 1980, Net-firing gun for capturing breeding waterfowl: Journal of Wildlife Management, v. 44, p. 895-896.

Mehl, K.R., Drake, K.L., Page, G.W., Sanzenbacher, P.M., Haig, S.M., and Thompson, J.E., 2003, Capture of breeding and wintering shorebirds with leg-hold noose-mats: Journal of Field Ornithology, v. 74, p. 401-405.

Mittelhauser, G.H., Tudor, L., and Connery, B., 2006, Distribution and ecology of purple sandpipers wintering in the Acadia National Park region, Maine 2001-2004: Boston, Mass., National Park Service, Technical Report NPS/NER/ NRTR-2006/048, 73 p.

Moon, J.A., and Haukos, D.A., 2009, Factors affecting body condition of Northern Pintails wintering in the Playa Lakes Region: Waterbirds, v. 32, p. 87-95.

Norwine, J., and Kuruvilla, J. (eds.), 2007, The changing climate of south Texas 1900-2100-Problems and prospects, impacts and implications: Texas A\&M-Kingsville, $158 \mathrm{p}$.

Oberholser, H.C., 1974, Bird life of Texas, v. 2: Austin, University of Texas Press.

Olalla-Kerstupp, A., 2010, Local and migratory movements, habitat use and threats of the Long-billed Curlew (Numenius americanus) in the Chihuahuan Desert, Mexico: San Nicolás de los Garza, Nuevo León, Universidad Autónoma de Nuevo León, Ph.D. dissertation, 44 p.

Oring, L., 2006, Long-billed Curlew Symposium: Wader Study Group Bulletin, v. 109, 30 p.

Pampush, G.J. and Anthony, R.G., 1993, Nest success, habitat utilization and nest-site selection of Long-billed Curlews in the Columbia Basin, Oregon: Condor, v. 95, p. 957-967.
Paton, P.W.C., and Dalton, J., 1994, Breeding ecology of Long-billed Curlews at Great Salt Lake, Utah: Great Basin Naturalist, v. 54, p. 79-85.

Piersma, T., Blomert, A.-M., and Klaassen, M., 1991, Valium against leg cramp in waders: Wader Study Group Bulletin, v. 63 , p. $39-41$.

Price, J.T., 1995, Potential impacts of global climate change on the summer distribution of some North American grassland birds: Detroit, Mich., Wayne State University, Ph.D. dissertation, $356 \mathrm{p}$.

Proudfoot, G.A., and Jacobs, E.A., 2001, Bow net equipped with radio alarm: Wildlife Society Bulletin, v. 29, p. 543-545.

Purchase, D., and Minton, C.D.T, 1982, Possible capture myopathy in Bar-tailed Godwits (Limosa lapponica) in Australia: Water Study Group Bulletin, v. 34, p. 24-26.

Rappole, J.H., 1995, The ecology of migrant birds a Neotropical perspective: Washington, D.C., Smithsonian Institution Press, $269 \mathrm{p}$.

Rappole, J.H., and Blacklock G.W., 1994, A field guideBirds of Texas: College Station, Tex., Texas A\&M University Press, $280 \mathrm{p}$.

Redmond, R.L., and Jenni, D.A., 1986, Population ecology of the Long-billed Curlew (Numenius americanus) in western Idaho: Auk, v. 103, p. 755-767.

Sikes, D., 2011, Help count the curlews: Corpus Christi Caller-Times, January 5, 2011, accessed May 31, 2011, at http://www.caller.com/news/2011/jan/05/help-count-thecurlews/.

Texas Parks and Wildlife Department, 2005, Texas Wildlife Action Plan, Comprehensive Wildlife Conservation Strategy: Austin, Tex., Texas Parks and Wildlife Dept., 1,131 p., accessed September 29, 2009, at http://www.tpwd. state.tx.us/publications/pwdpubs/pwd_pl_w7000_1187al.

U.S. Department of Agriculture, 2000, Summary report-1997 national resources inventory (revised December 2000): Washington, D.C., Natural Resources Conservation Service, and Ames, Iowa, Statistical Laboratory, Iowa State University, $89 \mathrm{p}$.

U.S. Fish and Wildlife Service, 2008, Birds of Conservation Concern 2008: Arlington, Va., United States Department of Interior, U. S. Fish and Wildlife Service, Division of Migratory Bird Management, 85 p., accessed on July 30, 2009, at http://www.fws.gov/migratorybirds/.

Wickersham, C.W., 1902, Sickle-billed Curlew: Auk, v. 19, p. 353-356. 
Wilson, F.H., 1937, A new species of Philopterus (Mallophaga) from the Long-billed Curlew: Canadian Entomologist, v. 64, p. $264-266$.

Woodin, M.C., Skoruppa, M.K., and Hickman, G.C., 2007, Winter ecology of the Burrowing Owl (Athene cuniclaria hypugaea) in Southern Texas 1999-2004: U.S. Geological Survey Scientific Investigations Report 2007-5150, 33 p.
Publishing support provided by: Rolla Publishing Service Center

For more information concerning this publication, contact: Director, USGS Northern Prairie Wildlife Research Center 8711 37th Street Southeast

Jamestown, North Dakota 58401

(701) 253-5553

Or visit the Northern Prairie Wildlife Research Center Web site at: http://npwrc.usgs.gov/ 


